\title{
CABLE PULLEY TEST
}

By:

\author{
Jason Nguyen \\ Bachelor of Engineering, Ryerson University (2018)
}

\author{
A project \\ presented to Ryerson University \\ in partial fulfilment of the \\ requirements for the degree of \\ Master of Engineering \\ in the program of
}

Aerospace Engineering

Toronto, Ontario, Canada, 2019

(C) Jason Nguyen 2019 


\section{AUTHOR'S DECLARATION FOR ELECTRONIC SUBMISSION OF A PROJECT}

I hereby declare that I am the sole author of this project. This is a true copy of the project, including any required final revisions, as accepted by my examiners.

I authorize Ryerson University to lend this project to other institutions or individuals for the purpose of scholarly research.

I further authorize Ryerson University to reproduce this project by photocopying or by other means, in total or in part, at the request of other institutions or individuals for the purpose of scholarly research.

I understand that my project may be made electronically available to the public. 


\title{
CABLE PULLEY TEST
}

Jason Nguyen

Master of Engineering, Aerospace Engineering, Ryerson University, Toronto (2019)

\begin{abstract}
This report will investigate the interactions regarding a cable pulley system within the nose landing gear. There is the possibility of tension drops occurring within this system. A test was done to determine the tension values within the system, this test was to isolate two possibilities that could cause the tension drop. These two possibilities were structural deflection within the nose landing gear or the tension loss occurring within the pulley cluster. With this test it was found that there are in fact tension drops when the pulley cluster was used on a rigid system without the structural deformations of the nose landing gear. There are some discrepancies where a basic cable test was done without the pulley cluster and no tension drop was found. This would lead to an investigation to occur after this test to determine why the tension drop happens with the cable and pulley cluster interaction. Some reasons to the tension drop within the pulley cluster would be unwinding of the cable as well as deformation occurring. There is however no definite answer for the tension drop as the observation was difficult within such a confined and small space of the pulley cluster.
\end{abstract}




\section{TABLE OF CONTENTS}

AUTHOR'S DECLARATION FOR ELECTRONIC SUBMISSION OF A PROJECT ............................................... ii

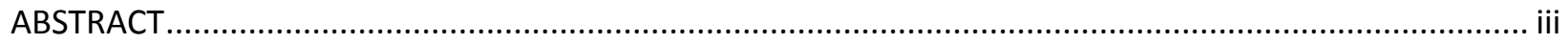

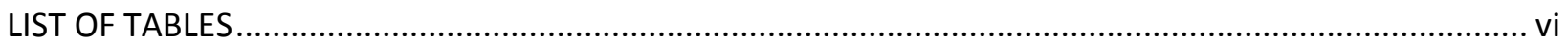

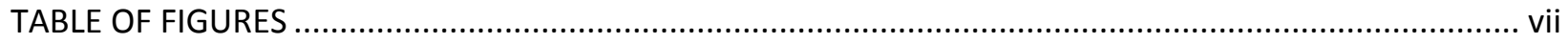

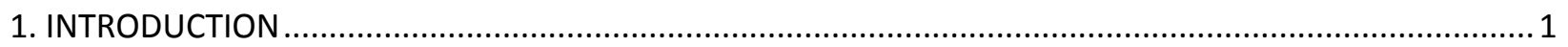

1.1 Scope

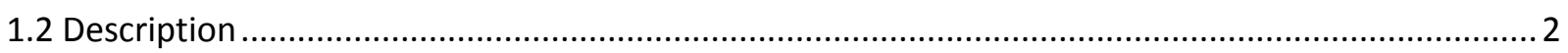

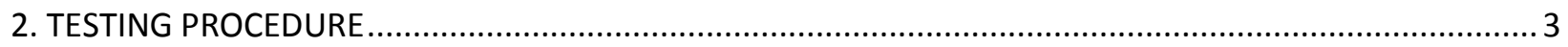

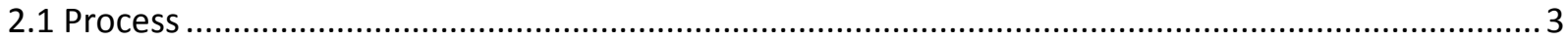

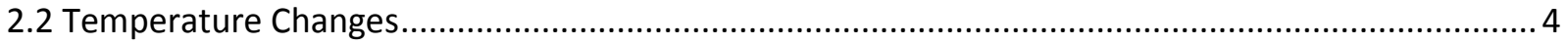

2.3 Procedure

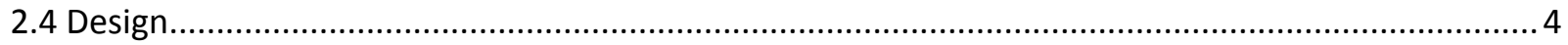

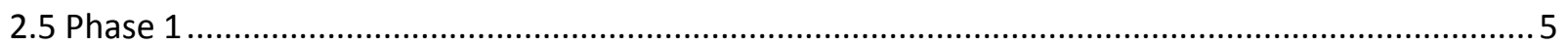

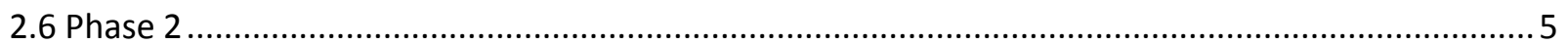

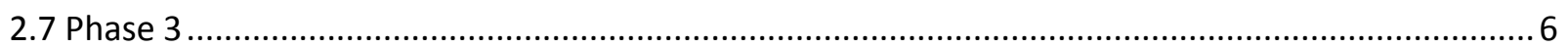

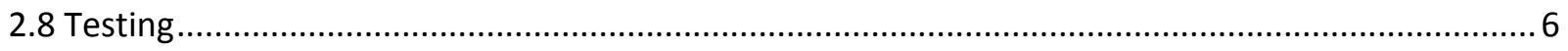

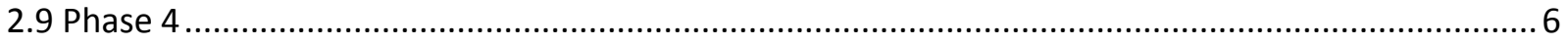

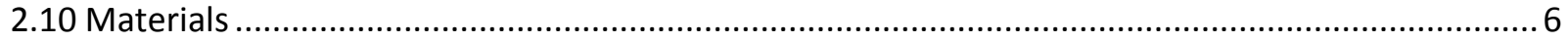

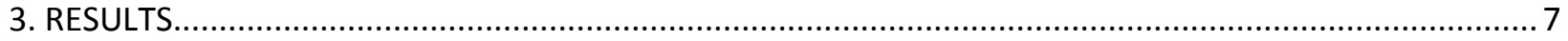

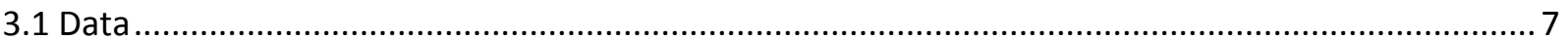

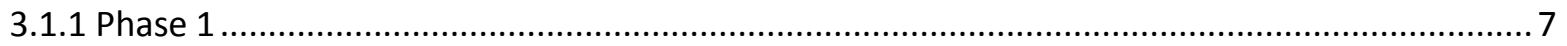

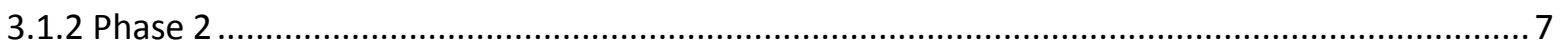

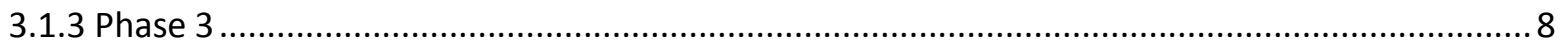

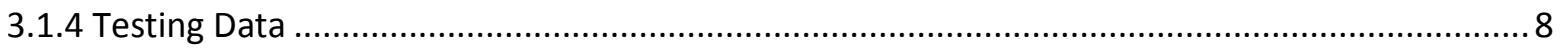

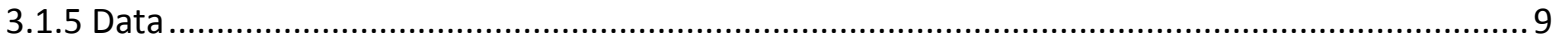

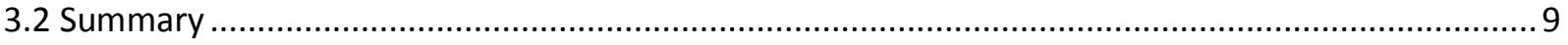

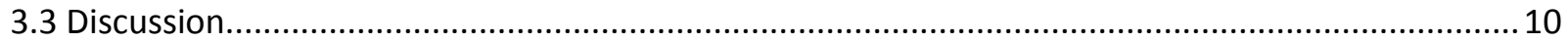

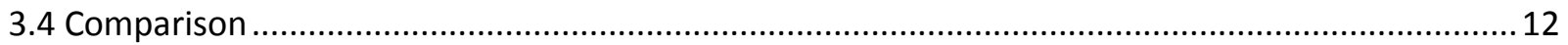

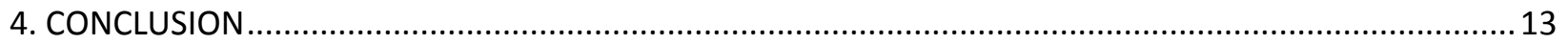

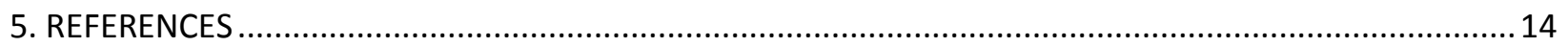

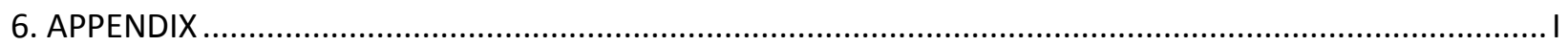

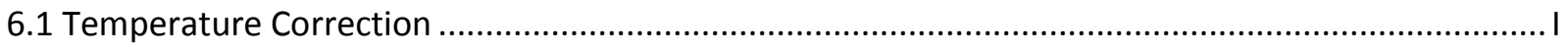




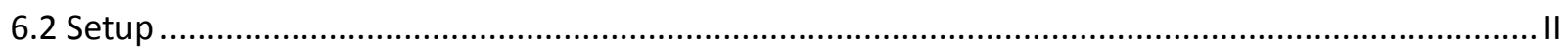

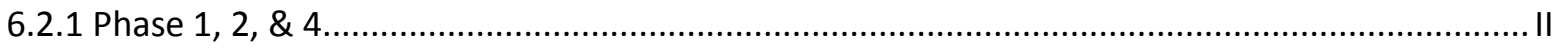

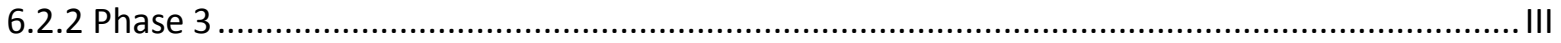

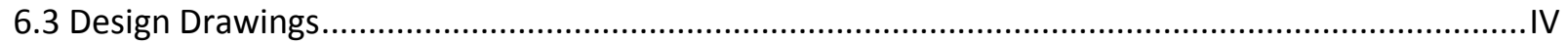

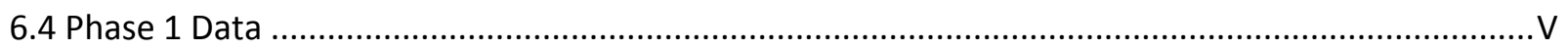

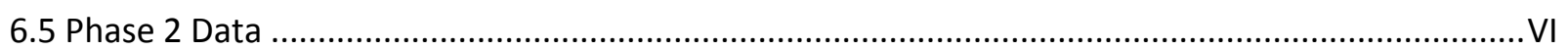

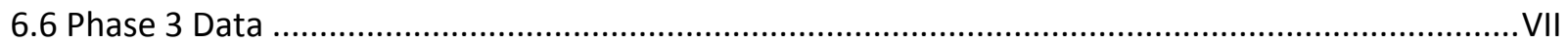

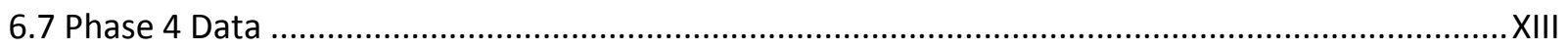




\section{LIST OF TABLES}

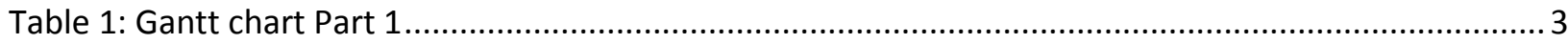

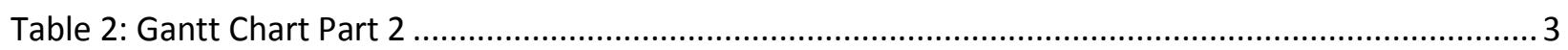

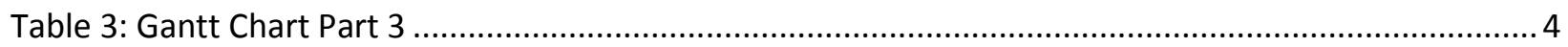

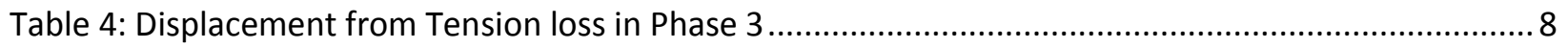

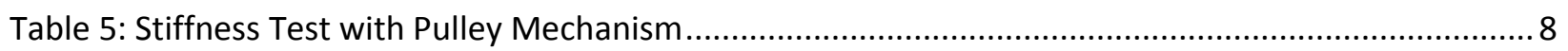

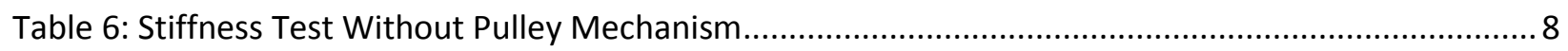

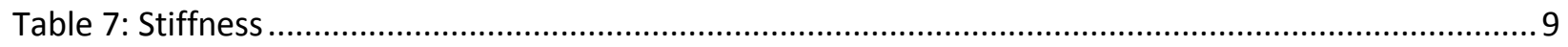

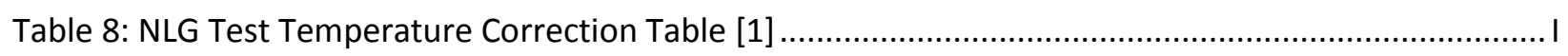

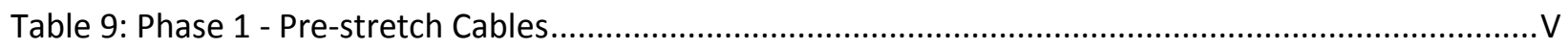

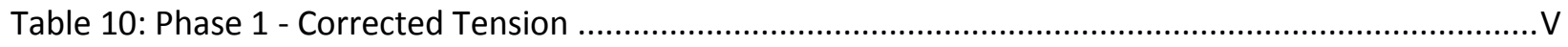

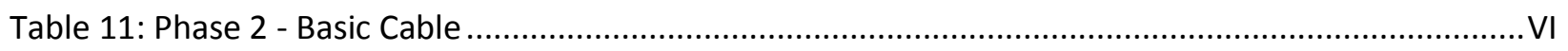

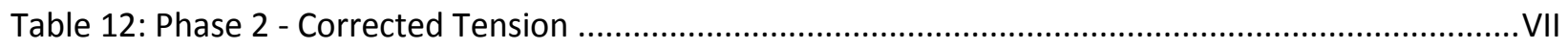

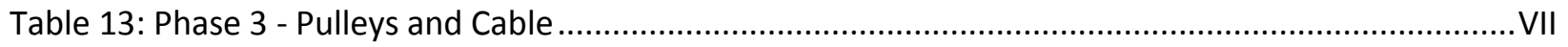

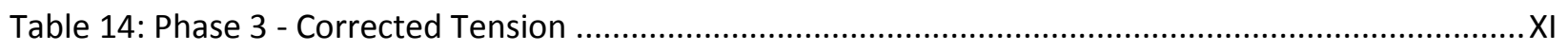

Table 15: Phase 4 - Basic Cable .......................................................................................................

Table 16: Phase 4 - Corrected Tension ............................................................................................... 


\section{TABLE OF FIGURES}

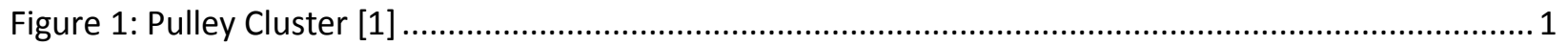

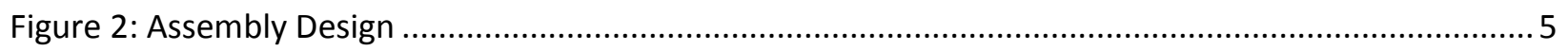

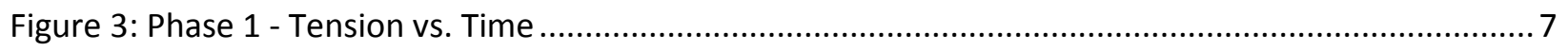

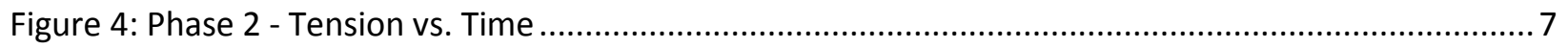

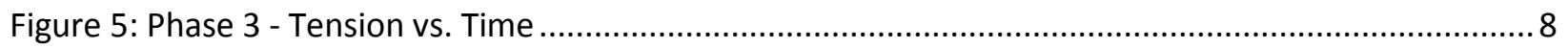

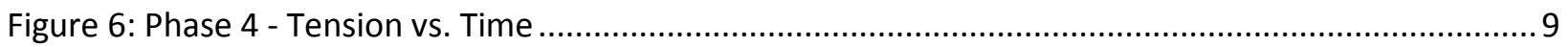

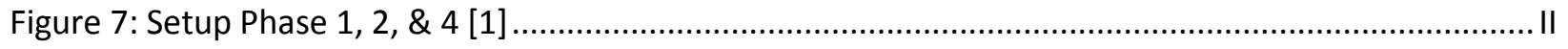

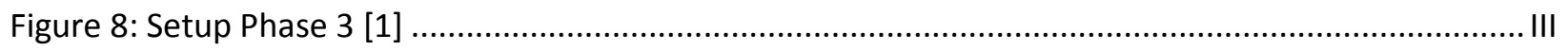

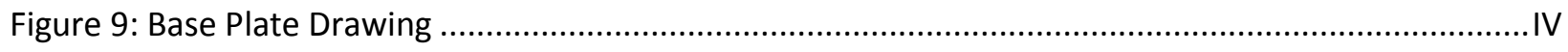

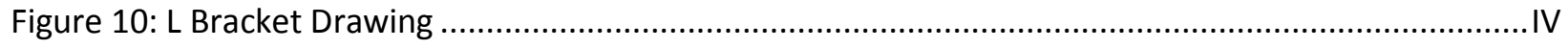

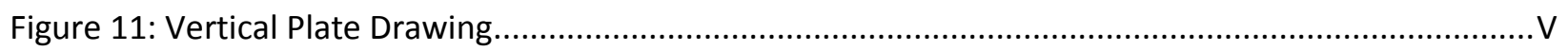

Figure 12: Phase 2 - Tension vs. Time, Adjusted Range ................................................................... VI 


\section{INTRODUCTION}

\subsection{Scope}

This project was to determine the of tension loss within a manual release system (MRS). For this test there is only one possibility of tension loss, this would be the cable creep over time. This is to isolate this single cause and see if this is the cause for the tension loss in the MRS. If the tension loss observed by this test is similar in magnitude as the loss observed, this would mean that cable creep is the only reason for tension loss in the manual release system.

The use of this project was to eliminate the structural deflection within the MRS in the NLG and determine how large of an impact cable creep is on the MRS. The project was intended to last for a total of 53 days,

- 4 days for phase 1 ,

- 14 days for phase 2 ,

- 14 days for phase 3,

- $\quad$ and 14 days for phase 4 .

However, the project had taken longer than anticipated and had lasted 119 days and extended the duration of phase 3. Phase 4 which will follow will still be two weeks as stated above. This project used the pulley system seen in figure 1 as provided by Safran Landing Systems (SLS). As previously stated, the project phases are now

- 4 days for phase 1 ,

- 14 days for phase 2 ,

- 87 days for phase 3.

- $\quad$ and 14 days for phase 4 .

This extension was due to the continuous tension loss that occurred with the involvement of the pulley cluster in phase 3 . That caused the continued observation of the system in phase 3 until an asymptotic trend was seen, this can be seen later in the report.

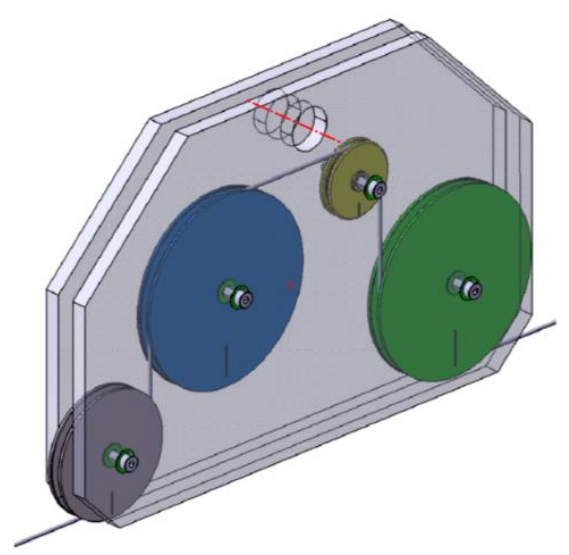

Figure 1: Pulley Cluster [1] 


\subsection{Description}

The possibility of the loss of tension due to the deformation of the manual release system is eliminated due to the simple and rigid structure of the testing apparatus. With the simplification of the system, it is easy to see how much tension loss is due to the cable creep as opposed to the structural apparatus. [1] Overall, the test did show tension loss when it comes to phase 3 where the pulley system was implemented into the test and thus there were signs to show that tension less was due to cable creep. This brings up the question of how much of tension was lost due to cable creep and does structural deflection even effect the cable tension in a real-world situation. 


\section{TESTING PROCEDURE}

\subsection{Process}

The process of testing the tension loss was like that of the process given by SLS. This process is as seen below

- Pre-stretch Cables (Phase 1) - 4-day test

- Basic Cable (Phase 2) - 14-day test

- Pulleys and Cable (Phase 3) - 14-day test

- Basic Cable (Phase 4) - 14-day test

However as stated previously, the test has changed to,

- Pre-stretch Cables (Phase 1) - 4-day test

- Basic Cable (Phase 2) - 14-day test

- Pulleys and Cable (Phase 3) - 87-day test

- Basic Cable (Phase 4) - 14-day test

The pulley system shown in figure 1 is the object given by SLS which will be used in the testing apparatus. The design of the testing apparatus was a simple design that focused on simplifying the design to show the effects of cable creep on the system with as little as any other causes for tension loss.

The testing of all the phases started on January $21^{\text {st }}$. This was the start of phase 1 where it will continue for four days. Afterwards phase 2 will start immediately after and continue for the next fourteen days. Phase 3 will continue after phase 2 and continued until a stabilized value was found. Again, a second basic cable phase will follow the conclusion of phase 3. A Gantt chart was created to show a timeline of the project duration to show the progression of each phase.

Table 1: Gantt chart Part 1

\begin{tabular}{|l|l|l|l|l|l|l|l|}
\hline & $01 / 07-$ & $01 / 14-$ & $01 / 21-$ & $01 / 28-$ & $02 / 04-$ & $02 / 11-$ & $02 / 18-$ \\
$01 / 14$ & $01 / 21$ & $01 / 28$ & $02 / 04$ & $02 / 11$ & $02 / 18$ & $02 / 25$ \\
\hline Tasks & & & & & & & \\
\hline Design \& Preparation & & & & & & & \\
\hline Phase 1: Pre-Stretch Cables & & & & & & & \\
\hline Phase 2: Basic Cables & & & & & & & \\
\hline Phase 3: Pulleys and Cables & & & & & & & \\
\hline Phase 4: Basic Cables & & & & & \\
\hline
\end{tabular}

Table 2: Gantt Chart Part 2

\begin{tabular}{|l|l|l|l|l|l|l|l|}
\hline & $02 / 25-$ & $03 / 4-$ & $03 / 11-$ & $03 / 18-$ & $03 / 25-$ & $04 / 01-$ & $04 / 08-$ \\
$03 / 04$ & $03 / 11$ & $03 / 18$ & $03 / 25$ & $04 / 01$ & $04 / 08$ & $04 / 15$ \\
\hline Tasks & & & & & & & \\
\hline Design \& Preparation & & & & & & & \\
\hline Phase 1: Pre-Stretch Cables & & & & & \\
\hline
\end{tabular}




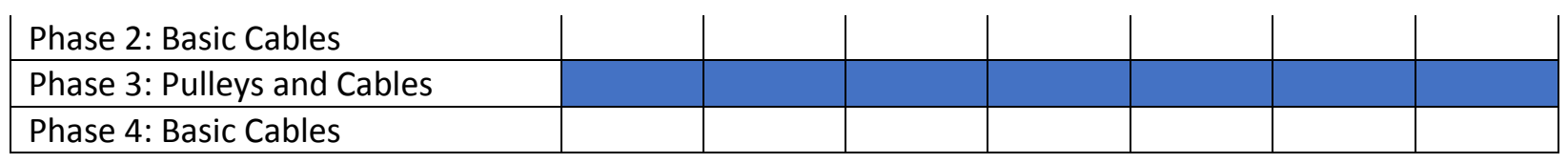

Table 3: Gantt Chart Part 3

\begin{tabular}{|l|l|l|l|l|l|l|}
\hline Tasks & $\begin{array}{l}04 / 15- \\
04 / 22\end{array}$ & $\begin{array}{l}04 / 22- \\
04 / 29\end{array}$ & $\begin{array}{l}04 / 29- \\
05 / 6\end{array}$ & $\begin{array}{l}05 / 06- \\
05 / 13\end{array}$ & $\begin{array}{l}05 / 13- \\
05 / 20\end{array}$ & $\begin{array}{l}05 / 20- \\
05 / 27\end{array}$ \\
\hline Design \& Preparation & & & & & & \\
\hline Phase 1: Pre-Stretch Cables & & & & & & \\
\hline Phase 2: Basic Cables & & & & & & \\
\hline Phase 3: Pulleys and Cables & & & & & & \\
\hline Phase 4: Basic Cables & & & & & & \\
\hline
\end{tabular}

\subsection{Temperature Changes}

The temperature around the system does change the tension values for the of the cable, however it is not as significant. The corrected values can be shown by the table below in the Appendix section 6.1 where the ambient temperature is used to find the corrected tension. This information was provided by SLS so that it can provide a correct tension value that is corrected to a single temperature value of $21^{\circ} \mathrm{C}$. This conversion table can be seen in the appendix.

\subsection{Procedure}

The general procedure for each phase remains the same, however there are a few alterations between the phases, such as the pulley cluster and preset tension values. The list below shows the general procedure for each phase.

1. Assemble the NLG cable according to the figure supplied for the specified phase

2. Use turnbuckles to change the tension until the cable approaches slackness

3. Verify connections in the system and ensure end supports are solid

4. Tighten turnbuckle to proper tension value for the given phase.

5. Record the tension and ambient temperature and repeat for the duration of the phase

These steps would be used to assist in setting up the different apparatus for each phase. For phases 1 and 2 will share the same setup while phase 3 will have a different setup. The setup for each phase can be seen in the appendix as well as in the ETR sent by SLS. The numbers on these figures correspond to the materials list from the ETR Rev. 1. [1]

\subsection{Design}

The design of the apparatus that holds the pully cluster together is a simple system. Figure two which can be seen below shows the image system. There were two plates that allow for adjustable height to hold the pulley cluster in place in case of a change of height is required when involving and removing the pulley cluster between phases. The design was focused on keeping the system parallel to the floor and be able to remain still for the duration of the testing with no outside interference. 


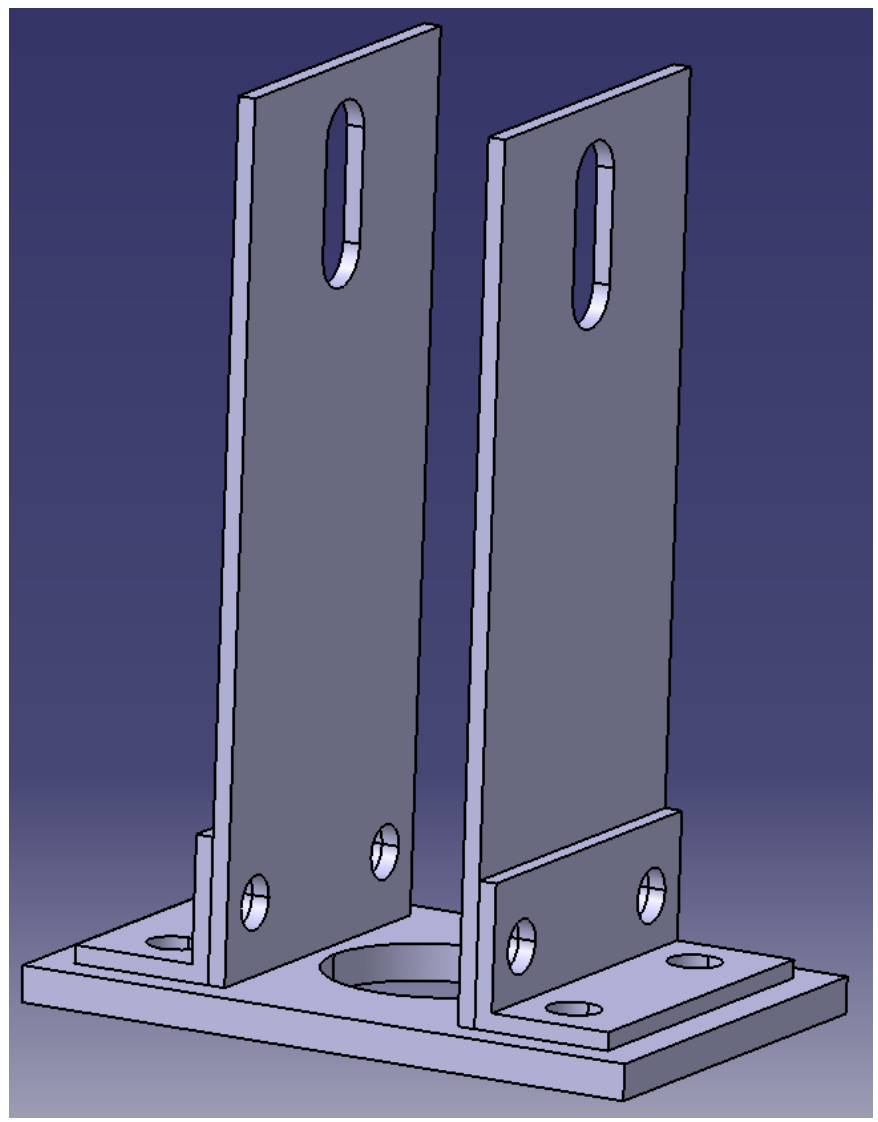

Figure 2: Assembly Design

This design was created to ensure that the pulley cluster would stay 14 inches above the ground. [1] This was done by creating a three-part design where a base plate, L-bracket, and vertical plate was used to hold the pulley cluster in place. This rigid structure would ensure that during testing of phase 3 , the pulley would not see movement as best as possible and not affect the results from phase 3 .

\subsection{Phase 1}

Phase one consisted of a short duration tension test. This test was to pre-stretch the cables at a high tension of 120 lbs for 96 hours ( 4 days). This initial phase was just the cable alone without the pulley system. This pre-stretch phase can help with the next few phases and will be discussed more in the results section of the report. Reporting each tension and temperature value every 24 hours from the start date to the end date.

\subsection{Phase 2}

This phase will be done by decreasing the tension in the pulley from $120 \mathrm{lbs}$ to $65 \mathrm{lbs}$. This is the main testing tension that most of the testing will be completed on. This is the main testing phase however this is done without the pulley cluster to compare with the next phase that will be completed after this one. This is important as there needs to be a comparison to see whether the cable or the pulley cluster is the cause of the tension loss. Thus, this entire phase consists of just a point to point connection of the cable and observation of the cable tension for a total of 14 days. Reporting each tension and temperature value every 24 hours from the start date to the end date. 


\subsection{Phase 3}

This is the third phase for the cable testing, this involves the pulley cluster. This phase will be tested at the same tension as Phase 2, 65lbs. With the pulley cluster involved in the apparatus, the cable passed through the pulleys within the cluster. This will change the system and possibly show changes in tension in the cable. The expectation is that the cable should not show any changes in tension however, there is a possibility that there will be a change. Reporting each tension and temperature value every 24 hours from the start date to the end date.

\subsection{Testing}

Some testing was done between phases three and four. This was to determine the stretch of the cable while the cable wraps around the pulleys, as well as without the pulleys. After change in tension seen at the end of phase three, this test was necessary. The test began with the change in length of the cable from the tension at the end of phase three $(55.3 \mathrm{lbs})$ to $65 \mathrm{lbs}$. This will give two points of data, one length at the end of phase three with the given tension and one with 65lbs and the change in length of the cable. Using these two data points, the stretch of the cable was determined which can be seen later in this paper. As well as dropping the tension from $65 \mathrm{lbs}$ to $25 \mathrm{lbs}$, from this $25 \mathrm{lbs}$ increasing the tension by increments of $25 \mathrm{lbs}$ until $100 \mathrm{lbs}$ and measuring stretch at each increment. The same was done after but without the pulley and only the cable. This test was run at the same parameters, starting at $25 \mathrm{lbs}$ and going up with increments of $25 \mathrm{lbs}$ until $100 \mathrm{lbs}$. This data will help find the stiffness of the cable.

\subsection{Phase 4}

For the final phase of testing, a basic cable test was observed for another two weeks after phase three. This phase was identical to that of phase two where only the cable was under tension without pulleys within the system. This phase is to ensure that the tension does not change after observing changes in phase three. There could be possible changes to the cable after the duration of phase three as the pulley cluster adds a new element to the system that could alter the cable.

\subsection{Materials}

The materials and objects required to do the test are the same from the SLS ETR report sent before starting the project. The pulleys in the cluster are made of two types of materials, three of the four pulleys are made from an aluminum alloy 6061 - T6 while the last pulley which is the smallest pulley of the four is not made of the same material. The cable is made of carbon steel with a tin over zinc coating. The plates that enclose the pulleys share the same material as the three aluminum alloy pulleys, aluminum alloy 6061 - T6. [1] The materials selection can be of importance when it comes to deformation. With the amount of deformation that can occur, the material selection of these parts can help lessen the factor of deformation and reduce possible tension loss due to the deformation of either the pulley or the plates of the enclosure of the pulleys. 


\section{RESULTS}

\subsection{Data}

\subsubsection{Phase 1}

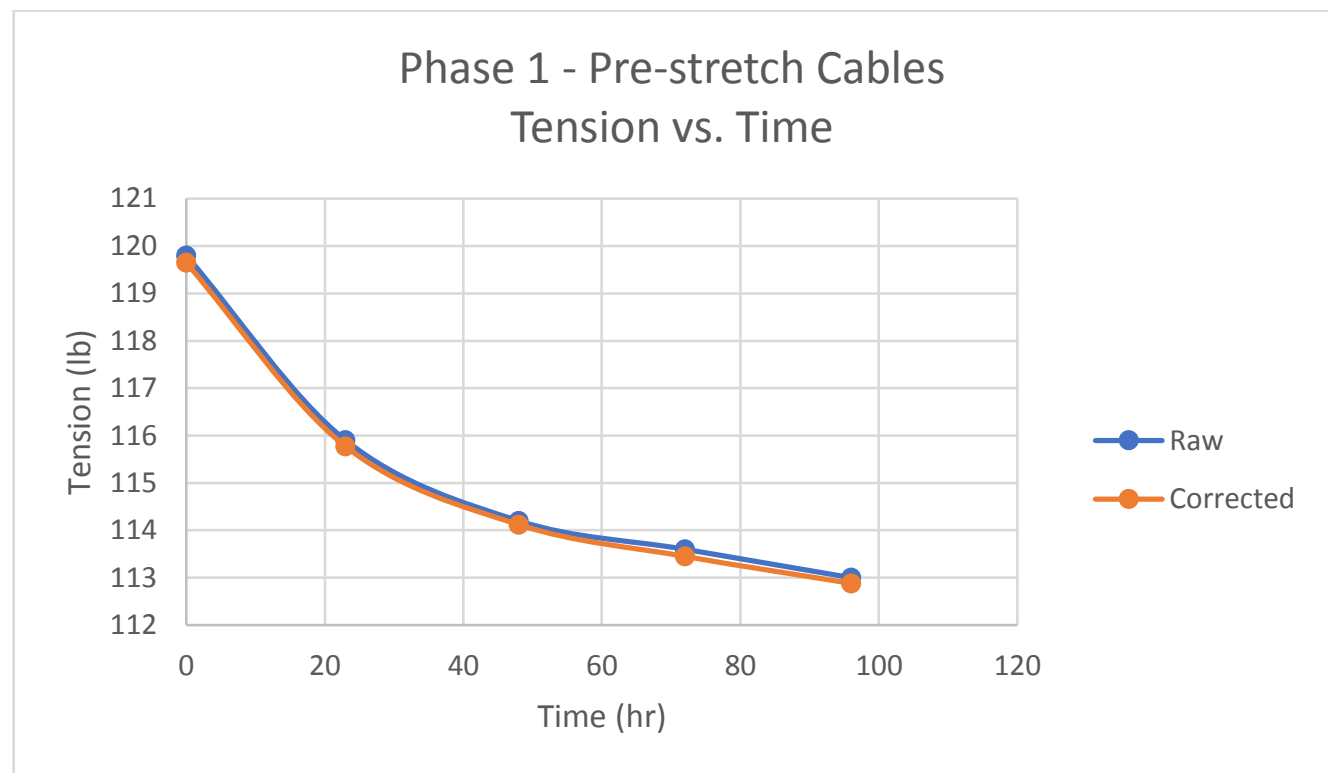

Figure 3: Phase 1 - Tension vs. Time

\subsubsection{Phase 2}

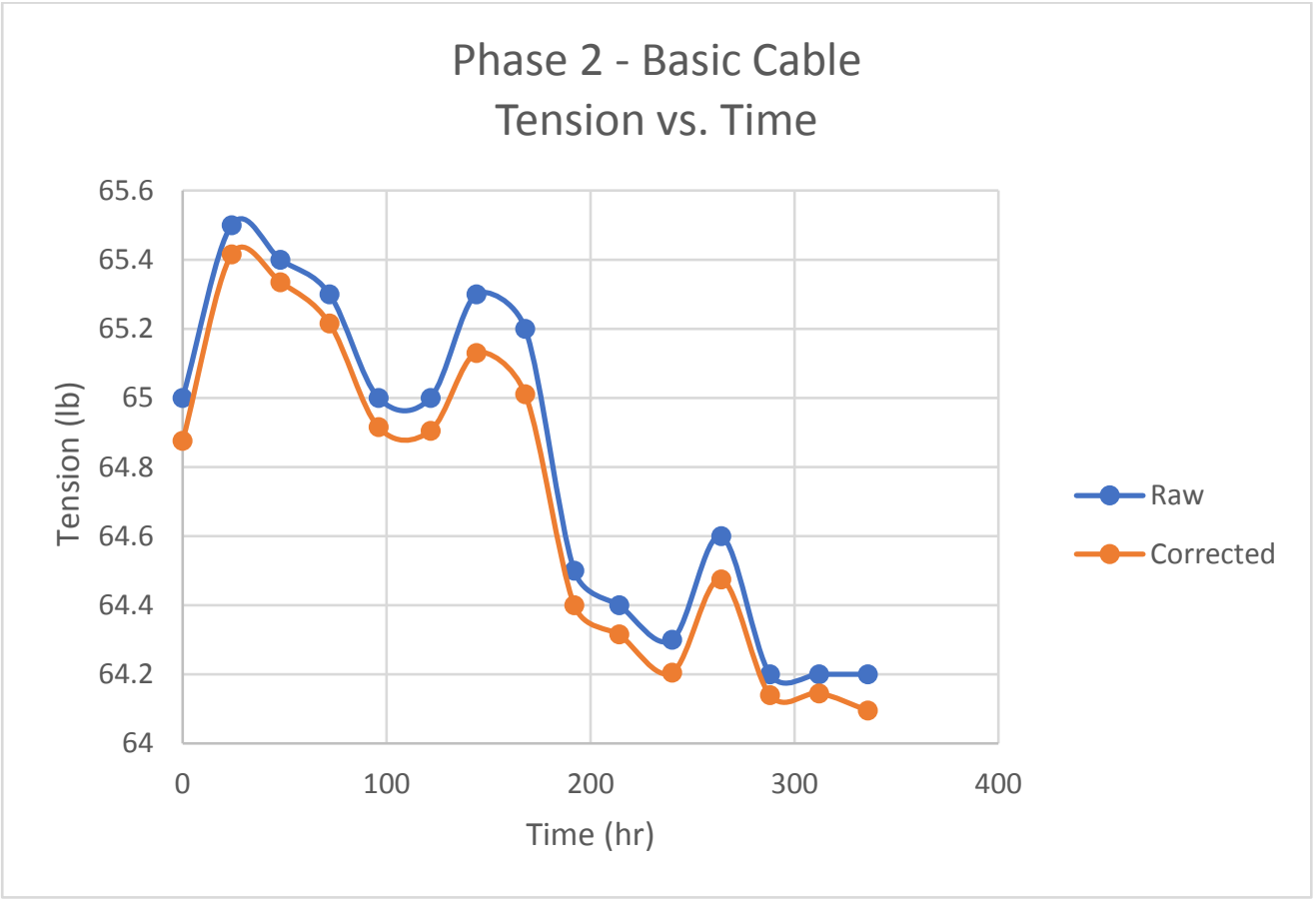

Figure 4: Phase 2 - Tension vs. Time 


\subsubsection{Phase 3}

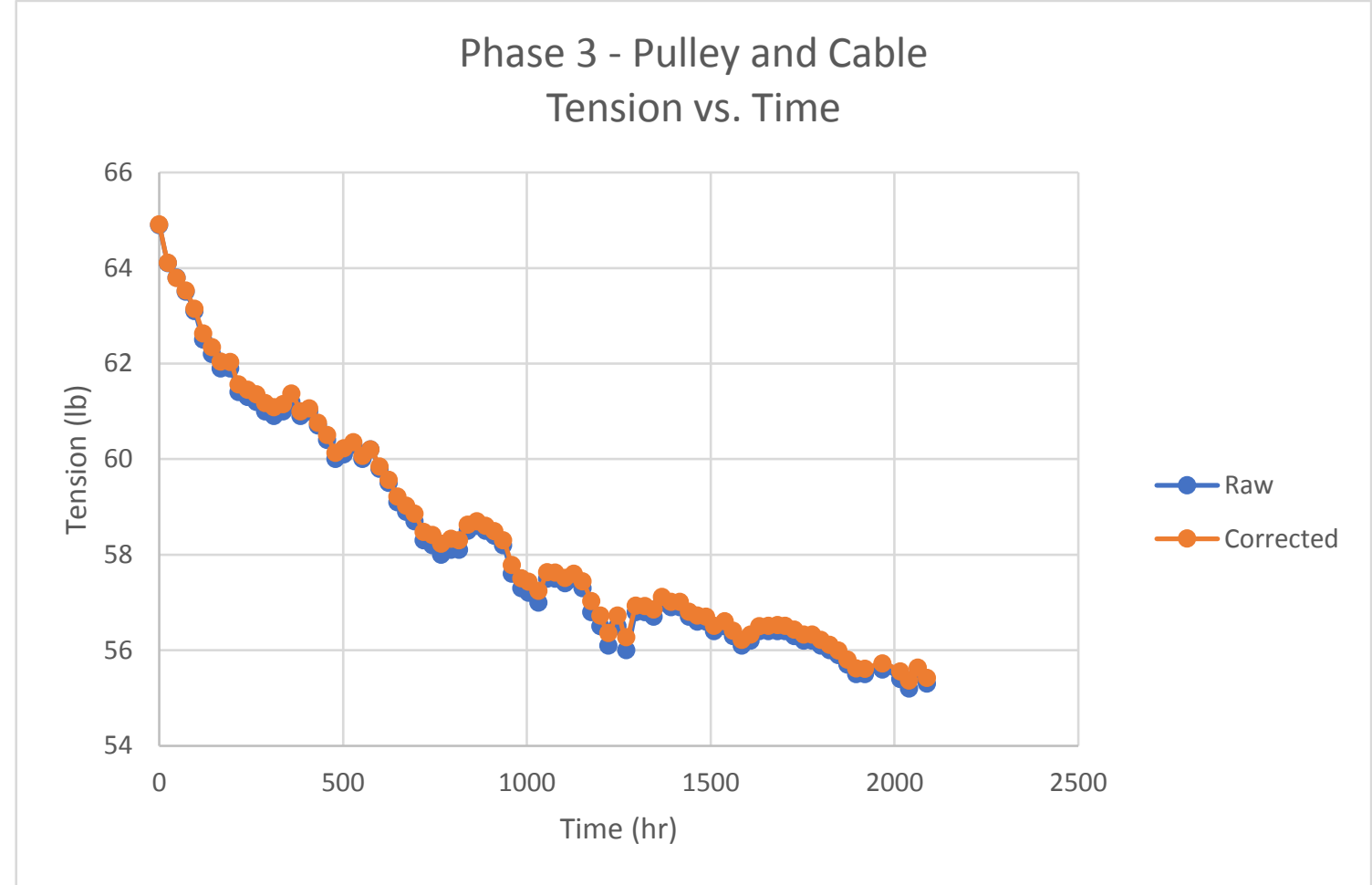

Figure 5: Phase 3 - Tension vs. Time

\subsubsection{Testing Data}

3.1.4.1 with the Pulley

Table 4: Displacement from Tension loss in Phase 3

\begin{tabular}{|c|c|}
\hline Load (lbs) & Displacement \\
\hline 55.2 & $X$ \\
\hline 65 & 0.007 \\
\hline
\end{tabular}

Table 5: Stiffness Test with Pulley Mechanism

\begin{tabular}{|c|c|c|c|}
\hline Load (lbs) & Measurement 1 & Measurement 2 & Displacement \\
\hline 25.4 & 7.19 & $\mathrm{X}$ & $\mathrm{X}$ \\
\hline 50.7 & 7.19 & 7.175 & 0.015 \\
\hline 75 & 7.175 & 7.162 & 0.013 \\
\hline 100.2 & 7.162 & 7.151 & 0.011 \\
\hline
\end{tabular}

\subsubsection{Without Pulley}

Table 6: Stiffness Test Without Pulley Mechanism

\begin{tabular}{|c|c|c|c|}
\hline Load (Ibs) & Measurement 1 & Measurement 2 & Displacement \\
\hline 25.1 & 7.742 & $\mathrm{X}$ & $\mathrm{X}$ \\
\hline 50.2 & 7.742 & 7.728 & 0.014 \\
\hline
\end{tabular}




\begin{tabular}{|c|c|c|c|}
\hline 75.3 & 7.728 & 7.716 & 0.012 \\
\hline 100 & 7.716 & 7.704 & 0.012 \\
\hline
\end{tabular}

Table 7: Stiffness

\begin{tabular}{|c|c|c|c|c|c|}
\hline \multicolumn{3}{|c|}{ With Pulley } & \multicolumn{3}{c|}{ Without Pulley } \\
\hline Load (Ib) & $\begin{array}{c}\text { Displacement } \\
\text { (in) }\end{array}$ & $\begin{array}{c}\text { Stiffness } \\
\text { (Ib/in) }\end{array}$ & Load (Ib) & $\begin{array}{c}\text { Displacement } \\
\text { (in) }\end{array}$ & $\begin{array}{c}\text { Stiffness } \\
\text { (Ib/in) }\end{array}$ \\
\hline 25.3 & 0.015 & 1686.67 & 25.1 & 0.014 & 1792.86 \\
\hline 24.3 & 0.013 & 1869.23 & 25.1 & 0.012 & 2091.67 \\
\hline 25.2 & 0.011 & 2290.91 & 24.7 & 0.012 & 2058.33 \\
\hline \multicolumn{3}{|c|}{ Average } & 1948.94 & \multicolumn{3}{c|}{ Average } & 1980.95 \\
\hline \multicolumn{3}{|c|}{ Average } & \multicolumn{3}{c|}{$1964.95 \mathrm{lb} /$ in } \\
\hline
\end{tabular}

\subsubsection{Data}

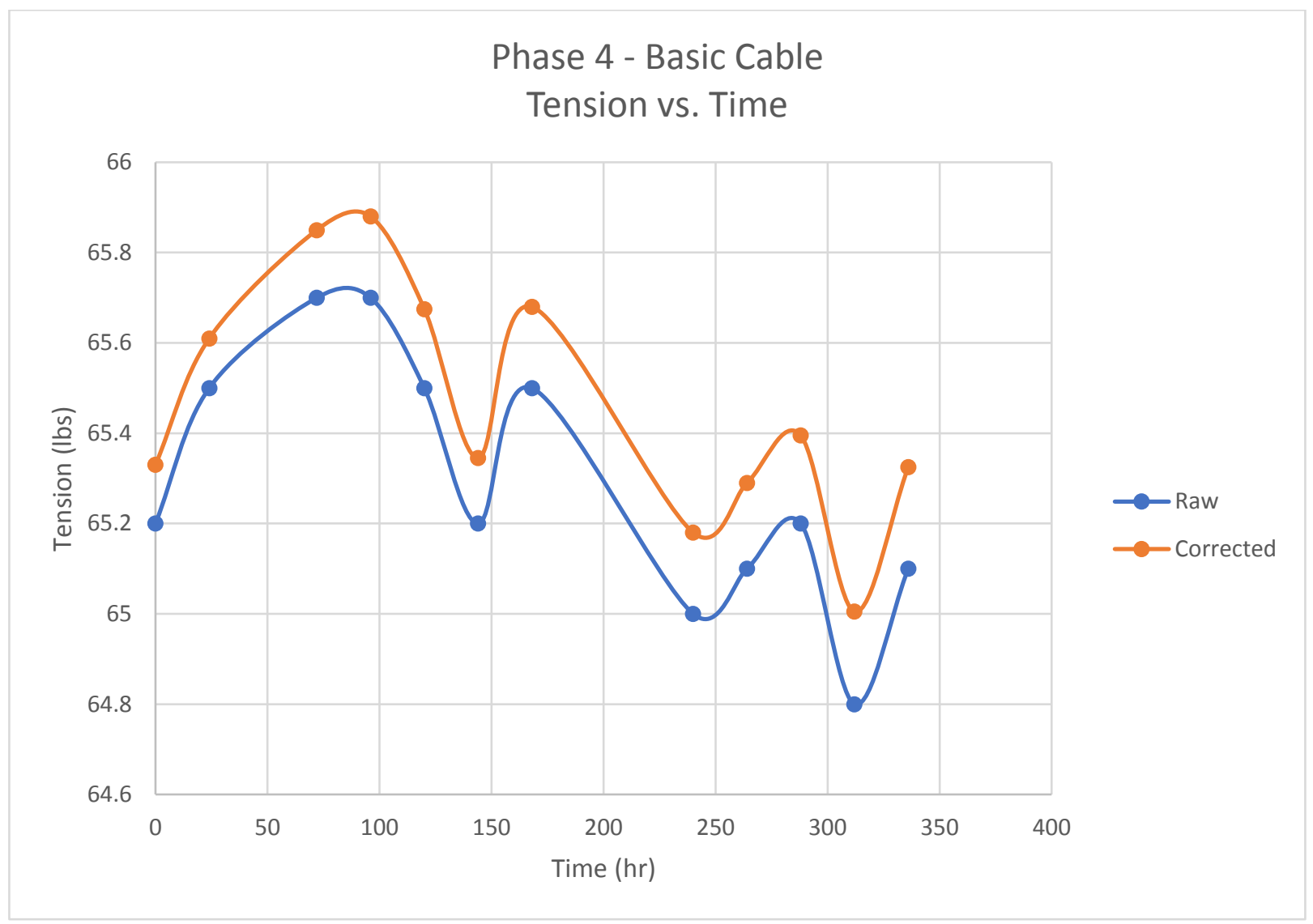

Figure 6: Phase 4 - Tension vs. Time

\subsection{Summary}

Overall in all the phases they showed fluctuations over the duration of the tests. However, the largest fluctuation was seen in Phase three of the test where it was extended to see the extent of the tension loss. In phase one the tension began with a slow drop that looked to plateau after the four-day 
test period. For phase two which was at a lower tension than phase one showed less fluctuations as it only changed by roughly $\pm 0.5 \mathrm{lbs}$ from $65 \mathrm{lbs}$. While phase four showed similar trends to phase two.

Phase 3 shows the largest difference when compared to the other two phases. The beginning of the test shows a significant drop within the first 200 hours of the test where the tension drops from $65 \mathrm{lbs}$ to $62 \mathrm{lbs}$. This is approximately a $5 \%$ drop from the initial tension of $65 \mathrm{lbs}$ within the week of testing. Further along the test, there were multiple drops that happen almost periodically. The tension proceeds to show a steady decrease and then increases suddenly to a larger drop. This is seen around $400,550,800,1100$, and 1300 hours. Only after a large duration of approximately 1600 hours there is a plateau seen around about $56.4 \mathrm{lbs}$ that fluctuates by $0.1 \mathrm{lbs}$.

The tension loss shown in phase three was not very promising. This led to some testing that was required at the end of phase three and before phase four could be done. Overall, there were three tests that were completed to help find the stiffness of the cable.

1. Obtaining two data points, from the current tension at the end of Phase three to $65 \mathrm{lbs}$.

2. Measuring the displacement of the cable when changing the tension in increments of $25 \mathrm{lbs}$ from $25 \mathrm{lbs}$ to $100 \mathrm{lbs}$ with the pulley cluster.

3. Measuring the displacement of the cable when changing the tension in increments of 25lbs from $25 \mathrm{lbs}$ to $100 \mathrm{lbs}$ without the pulley cluster.

\subsection{Discussion}

Phase one shows the pre-stretch phase where the system is setup according to figure 6 . The general purpose of this phase increases the general predictability of the cable. This phase just shows the twisted cable under tension without the pulley cluster. When the cable was stretched by the setup, the twisted cable has gotten longer, and each individual strand of the cable became more tightly packed. As a result the cross-section of the cable might have decreased slightly and the overall length of the cable would have increased. [2] This would bring a reduction in the diameter and increasing the length of the rope, however these change in values would be very slight and not that significant. [3] However, with the increase and lay length of the rope, the overall length of the cable will increase ever so slight.

The tension drop is very large over the entire phase 3 duration. This drop is over $10 \%$ of the original tension value of the cable. This is a large problem as this can be become an issue as it may affect the other parts within the system. As well the maintenance to keep this cable at $65 \mathrm{lbs}$ would be a problem in this current state. Thus, more investigation is required to fix this problem and find a way to keep the tension in this cable as constant as possible at 65lbs with the pulley cluster in the system.

Some possibilities that could cause this tension drop in the system would be three different reasons,

- deformation of the pulley,

- deformation of the rod that keeps the pulley rigid in the cluster,

- and the unwinding of the cable within the cluster. 
All these issues can contribute towards the tension drop that is seen in figure 5, however how severe each possibility would affect the system is the question. Whether or not all three issues will contribute or only two will is what needs to be investigated further.

The deformation of the pulley can show some decrease in the tension. The force that is pushing upon each pulley can cause the pulley to deform and cause the tension to drop. This is also dependent on the pulley themselves as the material can also determine the amount of deformation that occurs if any do. When the pulleys undergo deformation, the cable tension would decrease as the pulley radius where the cable wraps around the pulley would decrease.

The possibility that the cable will unwind within the pulley cluster is an issue. It is very difficult to determine if that is a problem in this current phase as within the cluster it is very difficult to observe. There is very little space to see if the cable unwinds within as well as the severity of the unwinding if it does occur. The unwinding is most likely to occur at moments where the cable will change direction. This would be at locations such as around the pulleys, how severe the unwinding would be would also depend on the curvature in which the cable is turning. This curvature would depend on the radius of the pulley and seeing that each of the pulleys have different radii, the unwinding of the cable would differ between the different pulley radii.

To help understand the cable better, a test was done to determine the stiffness of the twisted cable. With the cable under the figure 7 and 8 setup (with the pulley and without the pulley), a test with varying loads was completed to see the displacement of the cable within the apparatus. From the data set above, the largest displacement is seen when going from approximately $25 \mathrm{lbs}$ to $50 \mathrm{lbs}$, this is for the setup with and without the pulley. With both cases, it shows the same trend when increasing the load from $50 \mathrm{lbs}$ to $75 \mathrm{lbs}$ and $75 \mathrm{lbs}$ to $100 \mathrm{lbs}$ the displacement decreases when compared to the first point of data.

Table four shows two data points, one from the end of phase three as well as one to readjust the load to the starting tension of $65 \mathrm{lbs}$. Then measuring the length of both before and after the increase in tension to $65 \mathrm{lbs}$, the displacement can be found from the tension loss. This will help determine the stiffness of the cable.

Since the change in tension between each test is roughly the same at $25 \mathrm{lbs}$, the stiffness found by the displacement should be relatively the same. So, taking the average of all three test cases to find the stiffness of the cable with the pulley and without the pulley using the equation below. [4]

$$
k=\frac{\text { Change in Tension }}{\text { Displacement }}
$$

Shown in table 7 above, the stiffness of the cable is approximately $1964.95 \mathrm{lb} /$ inch when taking the average of both tests. This is reasonable as the increase in the load was very small and insignificant and only showed a small deflection or displacement.

The data shown for phase four is very similar to phase two. This is due to the same setup procedure as well as the same starting tension. The trend between both tests remain the same as described above. The overall tension of the cable is however stable, as the changes in tension are approximately $\pm 0.5 \mathrm{lbs}$ from a center of $65 \mathrm{lbs}$. This is a small fluctuation and if the test had continued the 
trend would likely continue. The tension loss that was seen in phase three was not seen in phase four, this would lead to the belief that the tension loss was completely due to the pulley cluster. More intensive research and testing would be required to determine what the cause of this tension loss was.

\subsection{Comparison}

All the phases show interesting trends when it comes to the different systems shown by figure 6 and 7. Phases 1 and 2 show the largest similarities as they share the same setup but have different initial tensions. The main difference between these two phases show that phase 1 , the pre-stretch phase has a constant decreasing tension while phase 2 , the basic pulley phase shows a fluctuation with a near constant tension. This is because when you have a pre-stretch phase at a higher tension than the primary tension, pre-stretch can help bring the cable elements closer together and increase the predictability of the cable and increase lay length. With the increase in lay length, the tension would decrease as the overall length of the cable would increase.

The more important comparison between phase 2 and phase 3 shows a very different trend. When comparing these two phases, the initial tension for both phases are the same however phase 2 will follow figure 6 while phase 3 will follow figure 7 . The different setups did show massive differences in trends when looking at the graphs for tension vs. time. These differences could be accounted for by the three issues brought up in the previous section, 3.3. All these issues cannot occur in phase 2 as there is no change in direction of the cable, as well as no deformation that can occur other than the deflection of the cable. Thus, it appears these tension drops seen in figure 5 , can be caused by the pulley cluster shown in figure 1. However, to find the root cause of the continuous tension drop further testing is required. Therefore, further investigation to the tension drop that occurs in phase 3 would be required to find a definite reasoning for the tension loss.

Some testing that could be done to further investigate this tension loss is the wrapping of the cable around the pulleys. A magnification of the bend around the pulley could reveal the cause of the tension drop that was seen in phase three and not seen in phase two and four. The main reason as to why there was no major tension drop seen in these two phases was the absence of the pulley cluster and no need to change direction of the cable. This would keep the cable twisted and intact where as there is a possibility of unwinding of the cable when changing directions or deformation of the pulley occurring. As well as the stiffness of the cable would vary around the turns of the pulley. 


\section{CONCLUSION}

The pulley cluster used in phase three showed some difficulty when attempting to run the test. The tension seemed to continue to drop for a prolonged amount of time with reasoning to believe that the pulley cluster is the cause of the tension drop. This is after a comparison between phase two and phase three results showing that the tension drop only occurs in phase three exclusively. The tension drops maybe caused by and not limited to the unwinding of the cable and deformation of the pulleys and/or pulley cluster. All these conclusions are speculations that require further investigation to find the exact cause and severity of this issue. 


\section{REFERENCES}

[1] B. Stisic and G. Ataman, "Global Express Manual Release System Cable," Safran Landing Systems, Ajax, 2018.

[2] Assembly Specialty Products, "Physical Properties of Wire Rope | Assembly Speciality Products," Assembly Specialty Products, [Online]. Available: https://www.assemblyspecialty.com/guide-towire-rope/technical-information/physical-properties-of-wire-rope/. [Accessed 27 April 2019].

[3] Cable Manufacturing \& Assembly Co., "CONSTRUCTIONAL STRETCH AND ELASTIC STRETCH: DO THEY ALTER YOUR CABLE DESIGN?," Cable Manufacturing \& Assembly Co., Bolivar.

[4] Engineering ToolBox, "Stiffness," Engineering ToolBox, 2008. [Online]. Available: https://www.engineeringtoolbox.com/stiffness-d_1396.html. [Accessed 1 June 2019].

[5] Eland Cables Limited, "FAQ: What is cable lay | Eland Cables," Eland Cable Limited [GB], [Online]. Available: https://www.elandcables.com/the-cable-lab/faqs/faq-what-is-cable-lay. [Accessed 25 April 2019]. 


\section{APPENDIX}

\subsection{Temperature Correction}

Table 8: NLG Test Temperature Correction Table [1]

\begin{tabular}{|c|c|c|}
\hline \multicolumn{2}{|c|}{ Ambient Temperature } & \multirow{2}{*}{$\begin{array}{c}\text { Cable Tension Correction } \\
\pm(\mathrm{lb})\end{array}$} \\
\hline$\left({ }^{\circ} \mathrm{C}\right)$ & $\left({ }^{\circ} \mathrm{F}\right)$ & \\
\hline 15 & 59 & -0.5 \\
\hline 16 & 61 & -0.4 \\
\hline 17 & 63 & -0.3 \\
\hline 18 & 64 & -0.3 \\
\hline 19 & 66 & -0.2 \\
\hline 20 & 68 & -0.1 \\
\hline 21 & 70 & 0 \\
\hline 22 & 72 & 0.1 \\
\hline 23 & 73 & 0.2 \\
\hline 24 & 75 & 0.3 \\
\hline 25 & 77 & 0.3 \\
\hline 26 & 79 & 0.4 \\
\hline 27 & 81 & 0.5 \\
\hline 28 & 82 & 0.6 \\
\hline 29 & 84 & 0.7 \\
\hline 30 & 86 & 0.8 \\
\hline 31 & 88 & 0.9 \\
\hline 32 & 90 & 1.0 \\
\hline 33 & 91 & 1.0 \\
\hline 34 & 93 & 1.1 \\
\hline 35 & 95 & 1.2 \\
\hline
\end{tabular}


6.2 Setup

6.2.1 Phase $1,2, \& 4$

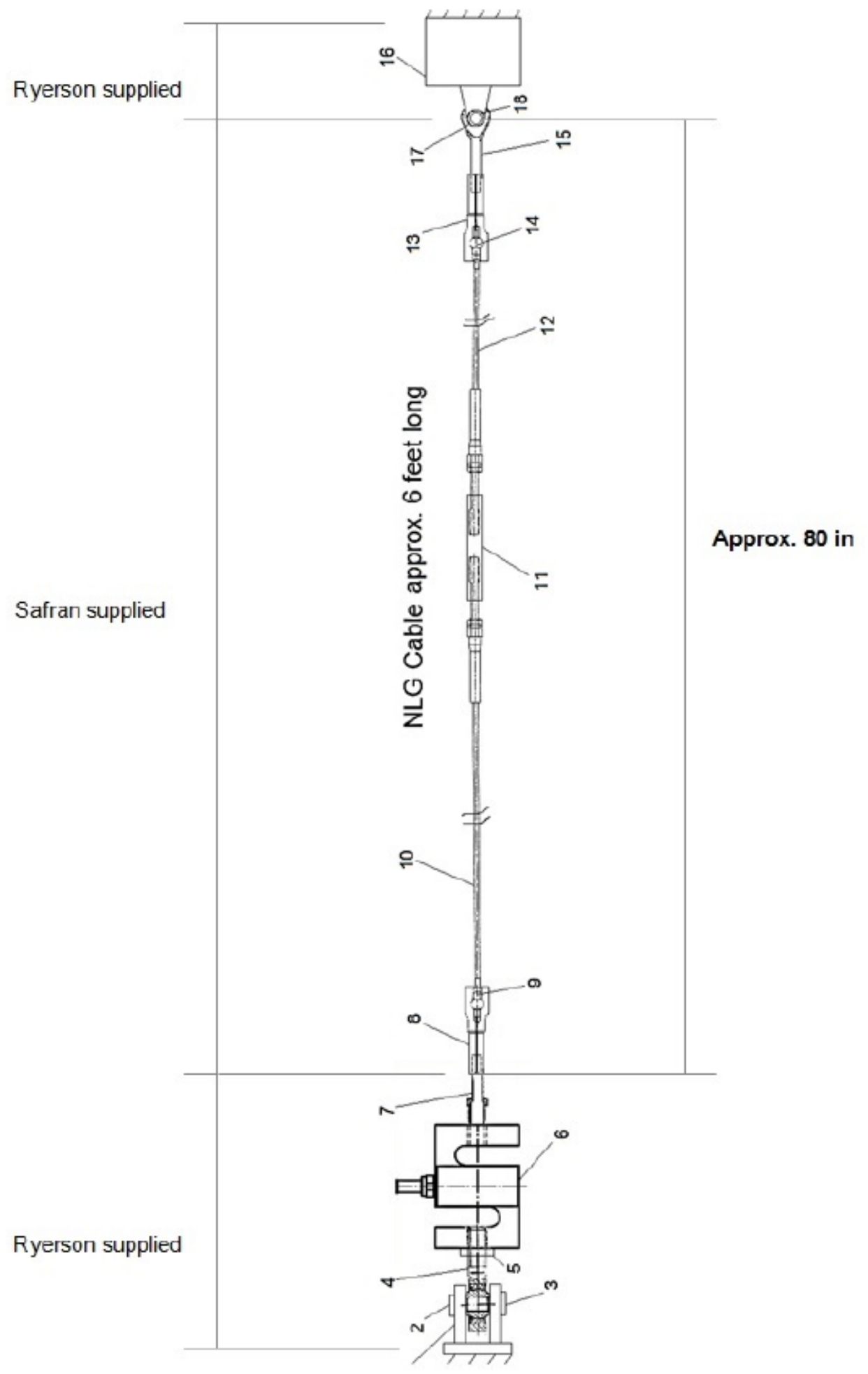

Figure 7: Setup Phase 1, 2, \& 4 [1] 
6.2.2 Phase 3

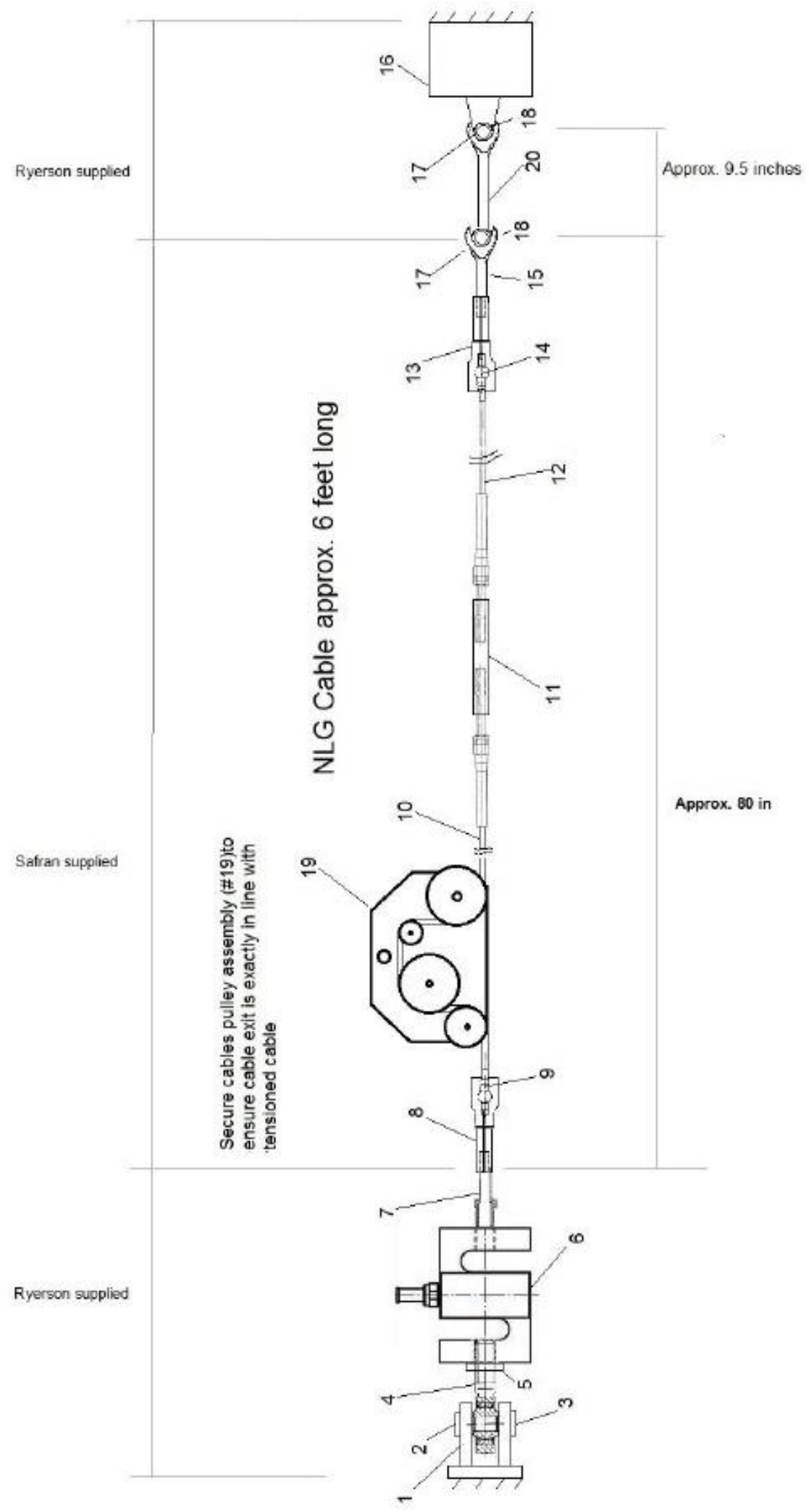

Figure 8: Setup Phase 3 [1] 
6.3 Design Drawings

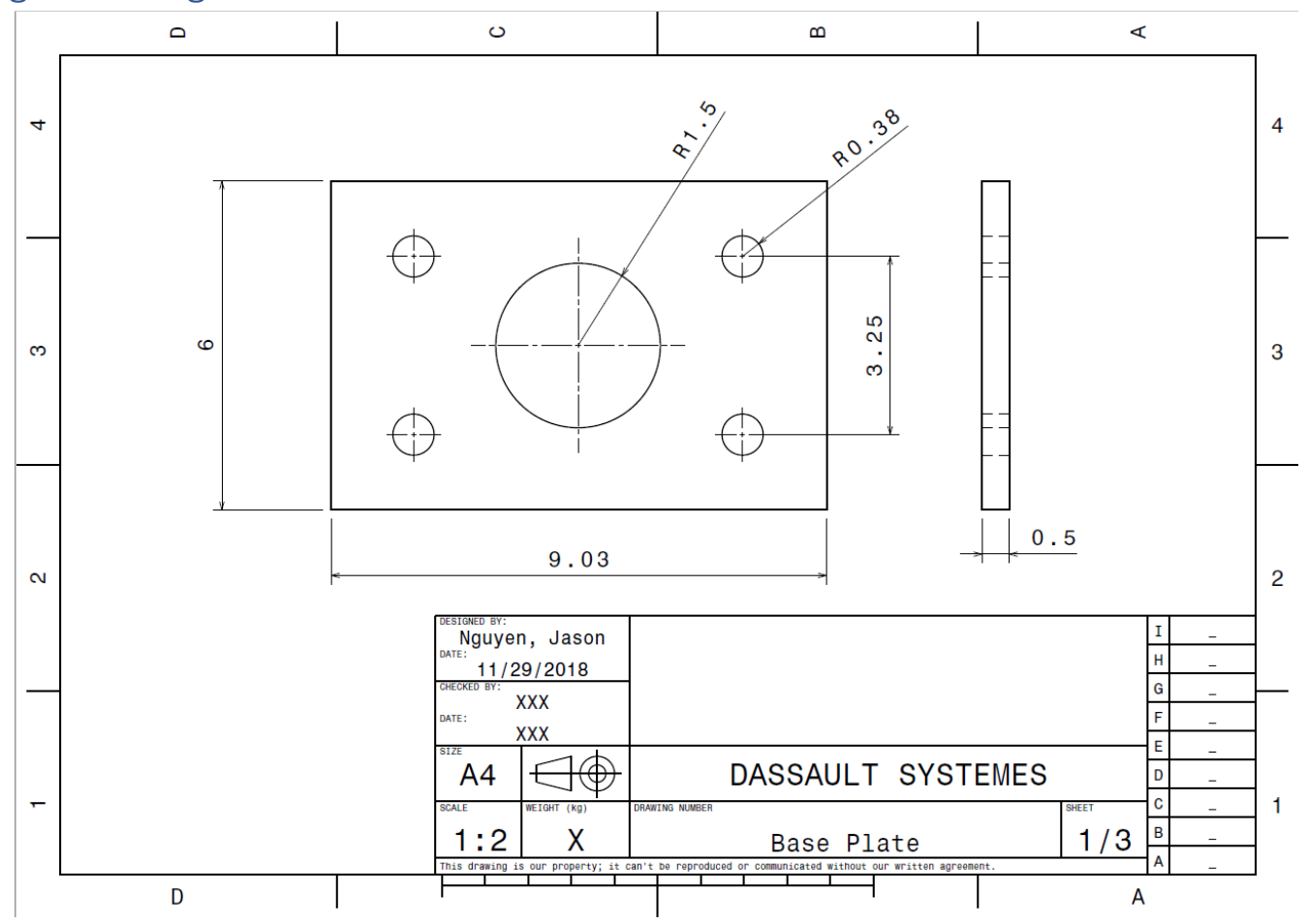

Figure 9: Base Plate Drawing

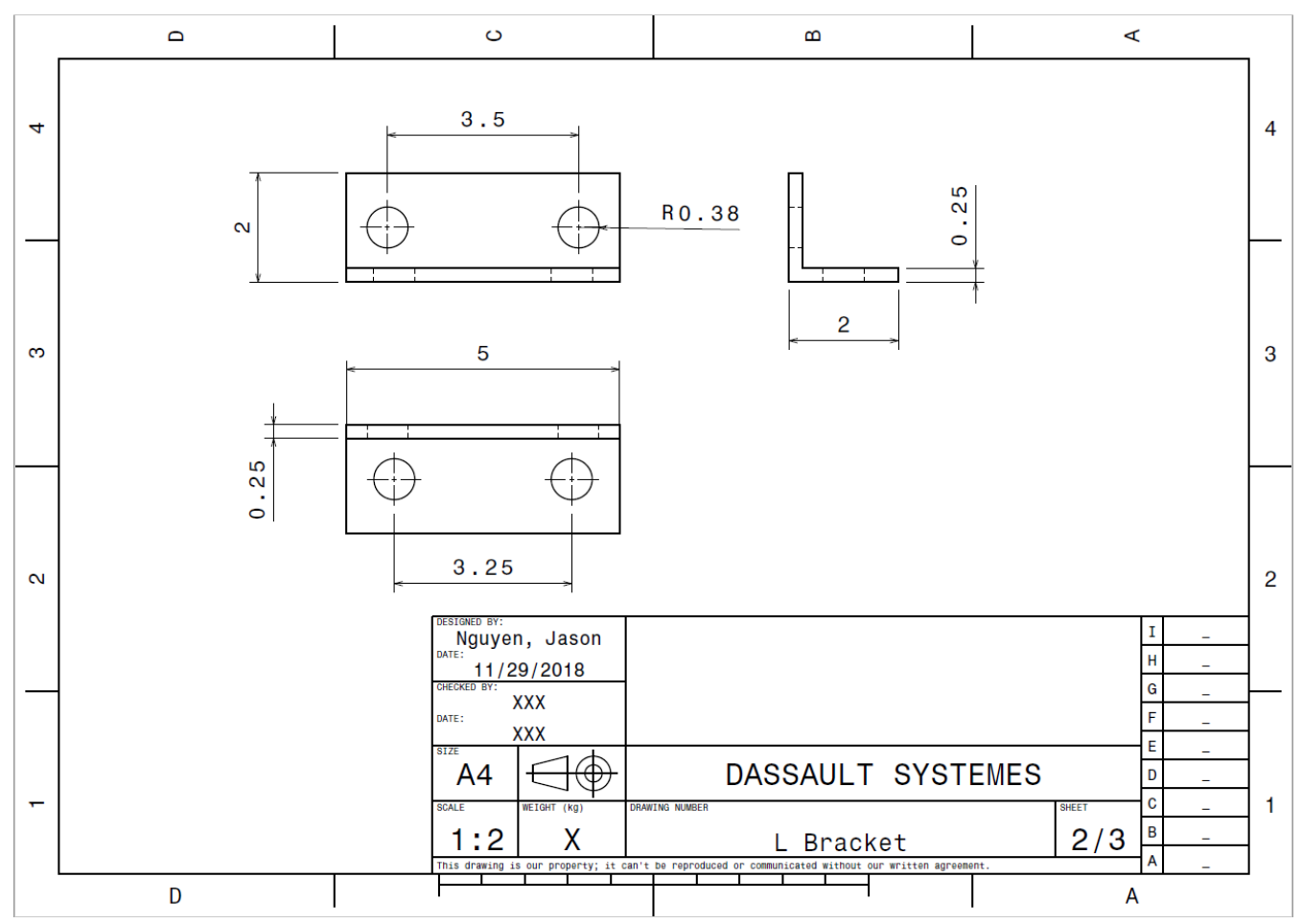

Figure 10: L Bracket Drawing 


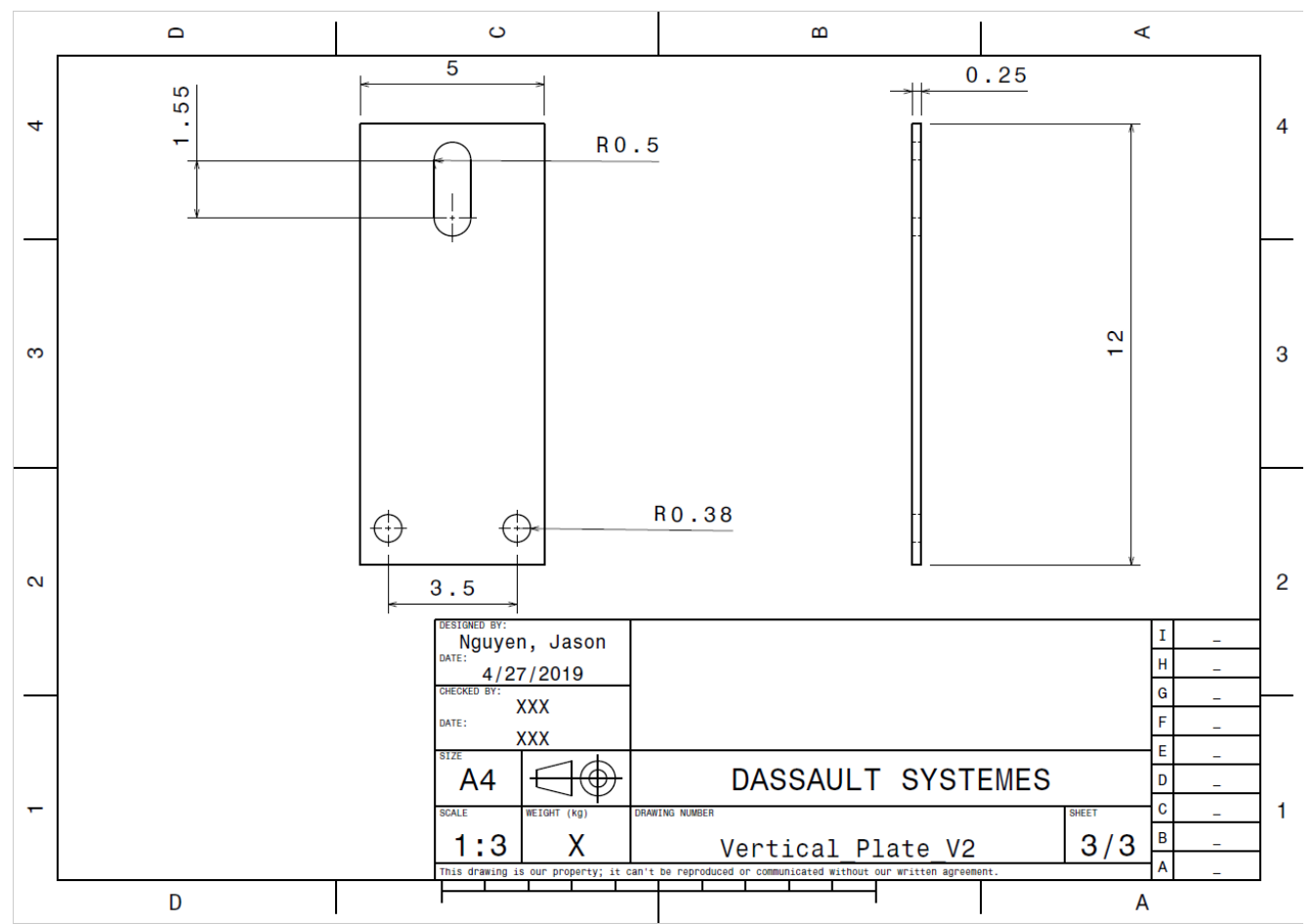

Figure 11: Vertical Plate Drawing

\subsection{Phase 1 Data}

Table 9: Phase 1 - Pre-stretch Cables

\begin{tabular}{|c|c|c|c|c|c|c|c|}
\hline Date & Day & Time & $\begin{array}{c}\text { Total Time } \\
(\mathrm{hrs})\end{array}$ & $\begin{array}{c}\text { Temperature 1 } \\
\left({ }^{\circ} \mathrm{C}\right)\end{array}$ & $\begin{array}{c}\text { Temperature } \\
2\left({ }^{\circ} \mathrm{C}\right)\end{array}$ & $\begin{array}{c}\text { Average } \\
\text { Temperature }\left({ }^{\circ} \mathrm{C}\right)\end{array}$ & $\begin{array}{c}\text { Tension } \\
(\mathrm{Ibs})\end{array}$ \\
\hline $\begin{array}{c}21- \\
\text { Jan }\end{array}$ & 0 & $10 \mathrm{~m}$ & 0 & 19.9 & 19.2 & 19.55 & 119.8 \\
\hline $\begin{array}{c}22- \\
\text { Jan }\end{array}$ & 1 & $9 a \mathrm{am}$ & 23 & 19.6 & 19 & 19.3 & 115.9 \\
\hline $\begin{array}{c}23- \\
\text { Jan }\end{array}$ & 2 & $10 \mathrm{am}$ & 48 & 20.5 & 19.9 & 20.2 & 114.2 \\
\hline $\begin{array}{c}24- \\
\text { Jan }\end{array}$ & 3 & $10: 30 a m$ & 72 & 19.7 & 19.3 & 19.5 & 113.6 \\
\hline $\begin{array}{c}25- \\
\text { Jan }\end{array}$ & 4 & $10 a m$ & 96 & 20.1 & 19.5 & 19.8 & 113 \\
\hline
\end{tabular}

Table 10: Phase 1 - Corrected Tension

\begin{tabular}{|c|c|c|}
\hline Day & Tension (lbs) & Corrected Tension(lbs) \\
\hline 0 & 119.8 & 119.645 \\
\hline 1 & 115.9 & 115.77 \\
\hline 2 & 114.2 & 113.4 \\
\hline 3 & 113.6 & 113.45 \\
\hline 4 & 113 & 112.88 \\
\hline
\end{tabular}




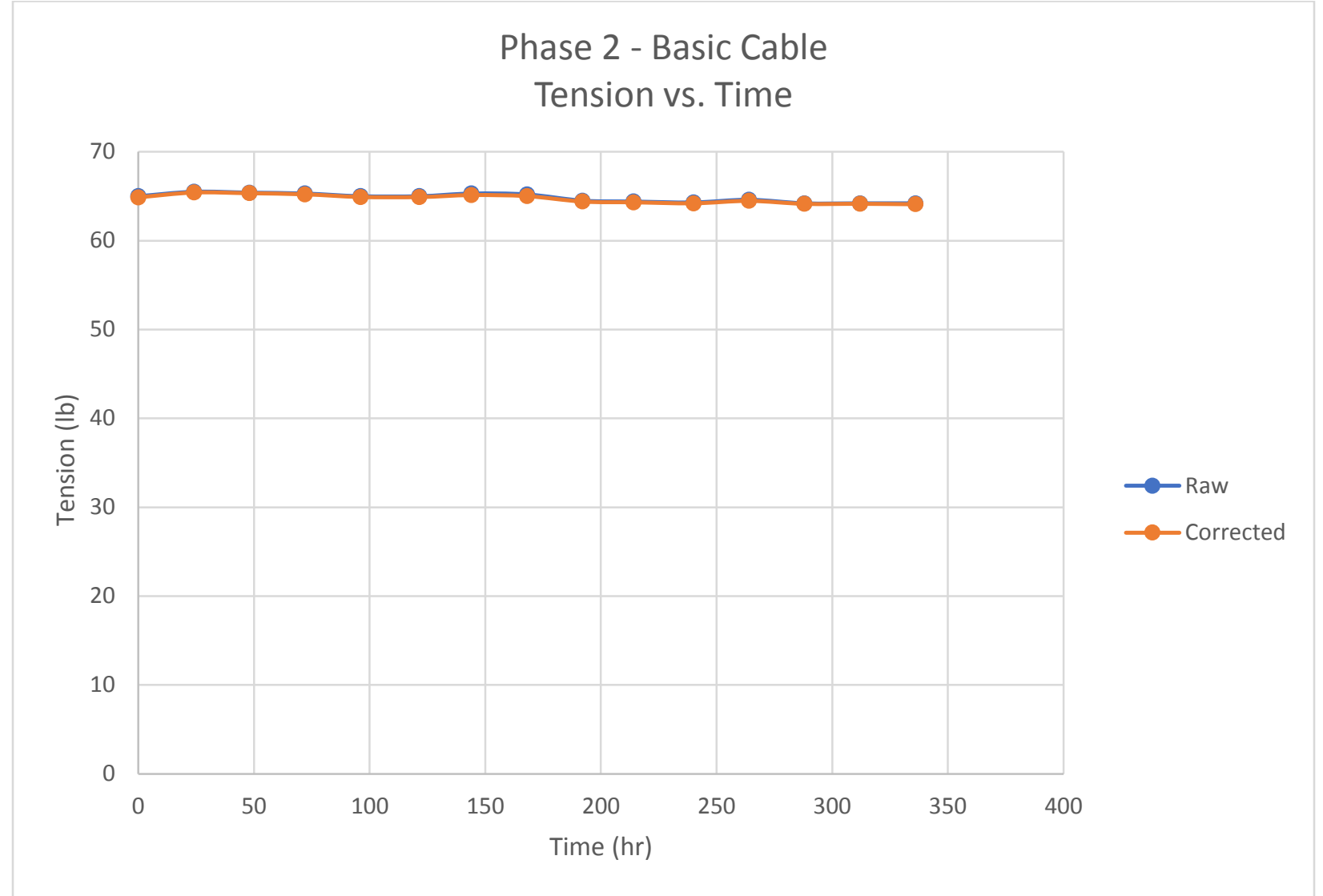

Figure 12: Phase 2 - Tension vs. Time, Adjusted Range

Table 11: Phase 2 - Basic Cable

\begin{tabular}{|c|c|c|c|c|c|c|c|}
\hline Date & Day & Time & $\begin{array}{c}\text { Total Time } \\
(\mathrm{hrs})\end{array}$ & $\begin{array}{c}\text { Temperature } \\
1\left({ }^{\circ} \mathrm{C}\right)\end{array}$ & $\begin{array}{c}\text { Temperature 2 } \\
\left({ }^{\circ} \mathrm{C}\right)\end{array}$ & $\begin{array}{c}\text { Average } \\
\text { Temperature }\left({ }^{\circ} \mathrm{C}\right)\end{array}$ & $\begin{array}{c}\text { Tension } \\
(\mathrm{lbs})\end{array}$ \\
\hline $\begin{array}{c}25- \\
\text { Jan }\end{array}$ & 0 & $12 \mathrm{pm}$ & 0 & 20.1 & 19.4 & 19.75 & 65 \\
\hline $\begin{array}{c}26- \\
\text { Jan }\end{array}$ & 1 & $12 \mathrm{pm}$ & 24 & 20.5 & 19.8 & 20.15 & 65.5 \\
\hline $\begin{array}{c}27- \\
\text { Jan }\end{array}$ & 2 & $12 \mathrm{pm}$ & 48 & 20.7 & 20 & 20.35 & 65.4 \\
\hline $\begin{array}{c}28- \\
\text { Jan }\end{array}$ & 3 & $12 \mathrm{pm}$ & 72 & 20.4 & 19.9 & 20.15 & 65.3 \\
\hline $\begin{array}{c}29- \\
\text { Jan }\end{array}$ & 4 & $12 \mathrm{pm}$ & 96 & 20.5 & 19.8 & 20.15 & 65 \\
\hline $\begin{array}{c}30- \\
\text { Jan }\end{array}$ & 5 & $1: 30 \mathrm{p}$ & 121.5 & 20.3 & 19.8 & 20.05 & 65 \\
\hline $\begin{array}{c}31- \\
\text { Jan }\end{array}$ & 6 & $12 \mathrm{pm}$ & 144 & 19.6 & 19 & 19.3 & 65.3 \\
\hline $\begin{array}{c}1- \\
\text { Feb }\end{array}$ & 7 & $12 \mathrm{pm}$ & 168 & 19.5 & 18.7 & 19.1 & 65.2 \\
\hline
\end{tabular}




\begin{tabular}{|c|c|c|c|c|c|c|c|}
\hline $\begin{array}{c}2- \\
\text { Feb }\end{array}$ & 8 & $12 \mathrm{pm}$ & 192 & 20.4 & 19.6 & 20 & 64.5 \\
\hline $\begin{array}{c}3- \\
\text { Feb }\end{array}$ & 9 & $10 \mathrm{am}$ & 214 & 20.5 & 19.8 & 20.15 & 64.4 \\
\hline $\begin{array}{c}4- \\
\text { Feb }\end{array}$ & 10 & $12 \mathrm{pm}$ & 240 & 20.2 & 19.9 & 20.05 & 64.3 \\
\hline $\begin{array}{c}5- \\
\text { Feb }\end{array}$ & 11 & $12 \mathrm{pm}$ & 264 & 20 & 19.5 & 19.75 & 64.6 \\
\hline $\begin{array}{c}6- \\
\text { Feb }\end{array}$ & 12 & $12 \mathrm{pm}$ & 288 & 20.8 & 20 & 20.4 & 64.2 \\
\hline $\begin{array}{c}7- \\
\text { Feb }\end{array}$ & 13 & $12 \mathrm{pm}$ & 312 & 20.7 & 20.2 & 20.45 & 64.2 \\
\hline $\begin{array}{c}8- \\
\text { Feb }\end{array}$ & 14 & $12 \mathrm{pm}$ & 336 & 20.2 & 19.7 & 19.95 & 64.2 \\
\hline
\end{tabular}

Table 12: Phase 2 - Corrected Tension

\begin{tabular}{|c|c|c|}
\hline Day & Tension (lbs) & Corrected Tension(lbs) \\
\hline 0 & 65 & 64.875 \\
\hline 1 & 65.5 & 65.415 \\
\hline 2 & 65.4 & 65.335 \\
\hline 3 & 65.3 & 65.215 \\
\hline 4 & 65 & 64.915 \\
\hline 5 & 65 & 64.905 \\
\hline 6 & 65.3 & 65.13 \\
\hline 7 & 65.2 & 65.01 \\
\hline 8 & 64.5 & 64.4 \\
\hline 9 & 64.4 & 64.315 \\
\hline 10 & 64.3 & 64.205 \\
\hline 11 & 64.6 & 64.475 \\
\hline 12 & 64.2 & 64.14 \\
\hline 13 & 64.2 & 64.145 \\
\hline 14 & 64.2 & 64.095 \\
\hline
\end{tabular}

\subsection{Phase 3 Data}

Table 13: Phase 3 - Pulleys and Cable

\begin{tabular}{|c|c|c|c|c|c|c|c|}
\hline Date & Day & Time & $\begin{array}{c}\text { Total Time } \\
(\mathrm{hrs})\end{array}$ & $\begin{array}{c}\text { Temperature } \\
1\left({ }^{\circ} \mathrm{C}\right)\end{array}$ & $\begin{array}{c}\text { Temperature 2 } \\
\left({ }^{\circ} \mathrm{C}\right)\end{array}$ & $\begin{array}{c}\text { Average } \\
\text { Temperature }\left({ }^{\circ} \mathrm{C}\right)\end{array}$ & $\begin{array}{c}\text { Tension } \\
(\mathrm{lbs})\end{array}$ \\
\hline $\begin{array}{l}11- \\
\text { Feb }\end{array}$ & 0 & $12 \mathrm{pm}$ & 0 & 21.3 & 21 & 21.15 & 64.9 \\
\hline $\begin{array}{l}12- \\
\text { Feb }\end{array}$ & 1 & $12 \mathrm{pm}$ & 24 & 21.2 & 21 & 21.1 & 64.1 \\
\hline $\begin{array}{l}13- \\
\text { Feb }\end{array}$ & 2 & $12 \mathrm{pm}$ & 48 & 21.1 & 20.7 & 20.9 & 63.8 \\
\hline
\end{tabular}




\begin{tabular}{|c|c|c|c|c|c|c|c|}
\hline $\begin{array}{l}\text { 14- } \\
\text { Feb }\end{array}$ & 3 & $12 \mathrm{pm}$ & 72 & 21.4 & 21.1 & 21.25 & 63.5 \\
\hline $\begin{array}{l}15- \\
\text { Feb }\end{array}$ & 4 & $12 \mathrm{pm}$ & 96 & 21.9 & 21 & 21.45 & 63.1 \\
\hline $\begin{array}{l}16- \\
\text { Feb }\end{array}$ & 5 & $12 \mathrm{pm}$ & 120 & 22.6 & 22 & 22.3 & 62.5 \\
\hline $\begin{array}{l}\text { 17- } \\
\text { Feb }\end{array}$ & 6 & $12 \mathrm{pm}$ & 144 & 22.6 & 22.3 & 22.45 & 62.2 \\
\hline $\begin{array}{l}18- \\
\text { Feb }\end{array}$ & 7 & $12 \mathrm{pm}$ & 168 & 22.6 & 22.2 & 22.4 & 61.9 \\
\hline $\begin{array}{l}\text { 19- } \\
\text { Feb }\end{array}$ & 8 & $1 \mathrm{pm}$ & 193 & 22.6 & 22 & 22.3 & 61.9 \\
\hline $\begin{array}{l}20- \\
\text { Feb }\end{array}$ & 9 & $12 \mathrm{pm}$ & 216 & 22.9 & 22.4 & 22.65 & 61.4 \\
\hline $\begin{array}{l}\text { 21- } \\
\text { Feb }\end{array}$ & 10 & $1 \mathrm{pm}$ & 241 & 22.8 & 22.3 & 22.55 & 61.3 \\
\hline $\begin{array}{l}22- \\
\text { Feb }\end{array}$ & 11 & $1 \mathrm{pm}$ & 265 & 22.9 & 22.3 & 22.6 & 61.2 \\
\hline $\begin{array}{l}\text { 23- } \\
\text { Feb }\end{array}$ & 12 & $12 \mathrm{pm}$ & 288 & 23 & 22.5 & 22.75 & 61 \\
\hline $\begin{array}{l}24- \\
\text { Feb }\end{array}$ & 13 & $12 \mathrm{pm}$ & 312 & 23 & 22.7 & 22.85 & 60.9 \\
\hline $\begin{array}{l}25- \\
\text { Feb }\end{array}$ & 14 & $1 \mathrm{pm}$ & 337 & 22.8 & 22.2 & 22.5 & 61 \\
\hline $\begin{array}{l}26- \\
\text { Feb }\end{array}$ & 15 & $12 \mathrm{pm}$ & 360 & 22 & 21.5 & 21.75 & 61.2 \\
\hline $\begin{array}{l}\text { 27- } \\
\text { Feb }\end{array}$ & 16 & $1 \mathrm{pm}$ & 385 & 22.3 & 21.7 & 22 & 60.9 \\
\hline $\begin{array}{l}28- \\
\text { Feb }\end{array}$ & 17 & $12 \mathrm{pm}$ & 408 & 21.9 & 21.4 & 21.65 & 61 \\
\hline $\begin{array}{c}\text { 1- } \\
\text { Mar }\end{array}$ & 18 & $12 \mathrm{pm}$ & 432 & 21.9 & 21.3 & 21.6 & 60.7 \\
\hline $\begin{array}{c}2- \\
\text { Mar }\end{array}$ & 19 & $1 \mathrm{pm}$ & 457 & 22.4 & 21.7 & 22.05 & 60.4 \\
\hline $\begin{array}{c}\text { 3- } \\
\text { Mar }\end{array}$ & 20 & $12 \mathrm{pm}$ & 480 & 22.5 & 22.1 & 22.3 & 60 \\
\hline $\begin{array}{c}\text { 4- } \\
\text { Mar }\end{array}$ & 21 & $11 \mathrm{am}$ & 503 & 22.4 & 22.1 & 22.25 & 60.1 \\
\hline $\begin{array}{c}5- \\
\text { Mar }\end{array}$ & 22 & $12 \mathrm{pm}$ & 528 & 21.7 & 21.4 & 21.55 & 60.3 \\
\hline $\begin{array}{c}\text { 6- } \\
\text { Mar }\end{array}$ & 23 & $1 \mathrm{pm}$ & 553 & 22 & 21.4 & 21.7 & 60 \\
\hline $\begin{array}{c}\text { 7- } \\
\text { Mar }\end{array}$ & 24 & $11 \mathrm{am}$ & 575 & 21.8 & 21.2 & 21.5 & 60.2 \\
\hline $\begin{array}{c}\text { 8- } \\
\text { Mar }\end{array}$ & 25 & $12 \mathrm{pm}$ & 600 & 21.7 & 21.2 & 21.45 & 59.8 \\
\hline
\end{tabular}




\begin{tabular}{|c|c|c|c|c|c|c|c|}
\hline $\begin{array}{c}\text { 9- } \\
\text { Mar }\end{array}$ & 26 & $1 \mathrm{pm}$ & 625 & 22 & 21.3 & 21.65 & 59.5 \\
\hline $\begin{array}{l}\text { 10- } \\
\text { Mar }\end{array}$ & 27 & $1 \mathrm{pm}$ & 648 & 22.3 & 22.1 & 22.2 & 59.1 \\
\hline $\begin{array}{l}\text { 11- } \\
\text { Mar }\end{array}$ & 28 & $1 \mathrm{pm}$ & 672 & 22.6 & 21.9 & 22.25 & 58.9 \\
\hline $\begin{array}{l}\text { 12- } \\
\text { Mar }\end{array}$ & 29 & $12 \mathrm{pm}$ & 695 & 22.8 & 22.3 & 22.55 & 58.7 \\
\hline $\begin{array}{l}13- \\
\text { Mar }\end{array}$ & 30 & $1 \mathrm{pm}$ & 720 & 23.1 & 22.5 & 22.8 & 58.3 \\
\hline $\begin{array}{l}\text { 14- } \\
\text { Mar }\end{array}$ & 31 & $12 \mathrm{pm}$ & 743 & 23.4 & 22.8 & 23.1 & 58.2 \\
\hline $\begin{array}{l}\text { 15- } \\
\text { Mar }\end{array}$ & 32 & $12 \mathrm{pm}$ & 767 & 23.5 & 23.1 & 23.3 & 58 \\
\hline $\begin{array}{l}\text { 16- } \\
\text { Mar }\end{array}$ & 33 & $3 p m$ & 794 & 23.5 & 23.1 & 23.3 & 58.1 \\
\hline $\begin{array}{l}\text { 17- } \\
\text { Mar }\end{array}$ & 34 & $1 \mathrm{pm}$ & 816 & 23.4 & 22.7 & 23.05 & 58.1 \\
\hline $\begin{array}{c}18- \\
\text { Mar }\end{array}$ & 35 & $1 \mathrm{pm}$ & 840 & 22.5 & 22 & 22.25 & 58.5 \\
\hline $\begin{array}{l}\text { 19- } \\
\text { Mar }\end{array}$ & 36 & $1 \mathrm{pm}$ & 864 & 22.3 & 21.7 & 22 & 58.6 \\
\hline $\begin{array}{l}20- \\
\text { Mar }\end{array}$ & 37 & $1 \mathrm{pm}$ & 888 & 22.3 & 21.7 & 22 & 58.5 \\
\hline $\begin{array}{l}\text { 21- } \\
\text { Mar }\end{array}$ & 38 & $1 \mathrm{pm}$ & 912 & 22.1 & 21.7 & 21.9 & 58.4 \\
\hline $\begin{array}{l}22- \\
\text { Mar }\end{array}$ & 39 & $1 \mathrm{pm}$ & 936 & 22.3 & 21.8 & 22.05 & 58.2 \\
\hline $\begin{array}{l}\text { 23- } \\
\text { Mar }\end{array}$ & 40 & $1 \mathrm{pm}$ & 960 & 23.1 & 22.6 & 22.85 & 57.6 \\
\hline $\begin{array}{l}\text { 24- } \\
\text { Mar }\end{array}$ & 41 & $2 p m$ & 985 & 23.3 & 22.8 & 23.05 & 57.3 \\
\hline $\begin{array}{l}\text { 25- } \\
\text { Mar }\end{array}$ & 42 & 10am & 1005 & 23.6 & 23.1 & 23.35 & 57.2 \\
\hline $\begin{array}{l}\text { 26- } \\
\text { Mar }\end{array}$ & 43 & $1 p m$ & 1032 & 23.7 & 23.2 & 23.45 & 57 \\
\hline $\begin{array}{l}\text { 27- } \\
\text { Mar }\end{array}$ & 44 & $1 \mathrm{pm}$ & 1056 & 22.6 & 22.1 & 22.35 & 57.5 \\
\hline $\begin{array}{c}28- \\
\text { Mar }\end{array}$ & 45 & 10am & 1077 & 22.6 & 21.9 & 22.25 & 57.5 \\
\hline $\begin{array}{l}29- \\
\text { Mar }\end{array}$ & 46 & $1 \mathrm{pm}$ & 1104 & 22.4 & 21.8 & 22.1 & 57.4 \\
\hline $\begin{array}{l}30- \\
\text { Mar }\end{array}$ & 47 & $1 \mathrm{pm}$ & 1128 & 22.3 & 21.8 & 22.05 & 57.5 \\
\hline $\begin{array}{l}\text { 31- } \\
\text { Mar }\end{array}$ & 48 & $1 \mathrm{pm}$ & 1152 & 22.7 & 22.1 & 22.4 & 57.3 \\
\hline
\end{tabular}




\begin{tabular}{|c|c|c|c|c|c|c|c|}
\hline $\begin{array}{c}\text { 1- } \\
\text { Apr }\end{array}$ & 49 & $1 \mathrm{pm}$ & 1176 & 23.5 & 23.1 & 23.3 & 56.8 \\
\hline $\begin{array}{c}2- \\
\text { Apr }\end{array}$ & 50 & $1 \mathrm{pm}$ & 1200 & 23.5 & 23 & 23.25 & 56.5 \\
\hline $\begin{array}{c}\text { 3- } \\
\text { Apr }\end{array}$ & 51 & 11am & 1222 & 23.9 & 23.3 & 23.6 & 56.1 \\
\hline $\begin{array}{l}\text { 4- } \\
\text { Apr }\end{array}$ & 52 & $12 \mathrm{pm}$ & 1247 & 23.6 & 23 & 23.3 & 56.5 \\
\hline $\begin{array}{c}5- \\
\text { Apr }\end{array}$ & 53 & $12 \mathrm{pm}$ & 1271 & 24 & 23.4 & 23.7 & 56 \\
\hline $\begin{array}{c}\text { 6- } \\
\text { Apr }\end{array}$ & 54 & $2 \mathrm{pm}$ & 1297 & 22.5 & 22.1 & 22.3 & 56.8 \\
\hline $\begin{array}{c}\text { 7- } \\
\text { Apr }\end{array}$ & 55 & $2 \mathrm{pm}$ & 1321 & 22.5 & 22 & 22.25 & 56.8 \\
\hline $\begin{array}{c}\text { 8- } \\
\text { Apr }\end{array}$ & 56 & $2 \mathrm{pm}$ & 1345 & 22.8 & 22.2 & 22.5 & 56.7 \\
\hline $\begin{array}{c}\text { 9- } \\
\text { Apr }\end{array}$ & 57 & $1 \mathrm{pm}$ & 1368 & 22.4 & 21.9 & 22.15 & 57 \\
\hline $\begin{array}{l}\text { 10- } \\
\text { Apr }\end{array}$ & 58 & $2 \mathrm{pm}$ & 1393 & 22.3 & 21.9 & 22.1 & 56.9 \\
\hline $\begin{array}{l}\text { 11- } \\
\text { Apr }\end{array}$ & 59 & $1 \mathrm{pm}$ & 1416 & 22.5 & 21.8 & 22.15 & 56.9 \\
\hline $\begin{array}{l}\text { 12- } \\
\text { Apr }\end{array}$ & 60 & $2 p m$ & 1441 & 22.3 & 21.8 & 22.05 & 56.7 \\
\hline $\begin{array}{l}\text { 13- } \\
\text { Apr }\end{array}$ & 61 & $1 \mathrm{pm}$ & 1464 & 22.5 & 22.1 & 22.3 & 56.6 \\
\hline $\begin{array}{l}\text { 14- } \\
\text { Apr }\end{array}$ & 62 & $1 \mathrm{pm}$ & 1488 & 22.4 & 21.6 & 22 & 56.6 \\
\hline $\begin{array}{l}\text { 15- } \\
\text { Apr }\end{array}$ & 63 & 11am & 1510 & 22.4 & 21.9 & 22.15 & 56.4 \\
\hline $\begin{array}{l}\text { 16- } \\
\text { Apr }\end{array}$ & 64 & $3 p m$ & 1538 & 22.4 & 21.7 & 22.05 & 56.5 \\
\hline $\begin{array}{l}\text { 17- } \\
\text { Apr }\end{array}$ & 65 & $2 \mathrm{pm}$ & 1561 & 22.3 & 21.9 & 22.1 & 56.3 \\
\hline $\begin{array}{l}\text { 18- } \\
\text { Apr }\end{array}$ & 66 & $2 p m$ & 1585 & 22.4 & 21.9 & 22.15 & 56.1 \\
\hline $\begin{array}{l}\text { 19- } \\
\text { Apr }\end{array}$ & 67 & $2 p m$ & 1609 & 22.5 & 22.1 & 22.3 & 56.2 \\
\hline $\begin{array}{l}\text { 20- } \\
\text { Apr }\end{array}$ & 68 & $2 \mathrm{pm}$ & 1633 & 22.3 & 21.8 & 22.05 & 56.4 \\
\hline $\begin{array}{l}\text { 21- } \\
\text { Apr }\end{array}$ & 69 & $2 \mathrm{pm}$ & 1657 & 22.4 & 21.9 & 22.15 & 56.4 \\
\hline $\begin{array}{l}\text { 22- } \\
\text { Apr }\end{array}$ & 70 & $3 p m$ & 1682 & 22.6 & 21.9 & 22.25 & 56.4 \\
\hline $\begin{array}{l}\text { 23- } \\
\text { Apr }\end{array}$ & 71 & $12 \mathrm{pm}$ & 1703 & 22.4 & 21.9 & 22.15 & 56.4 \\
\hline
\end{tabular}




\begin{tabular}{|c|c|c|c|c|c|c|c|}
\hline $\begin{array}{l}\text { 24- } \\
\text { Apr }\end{array}$ & 72 & $1 \mathrm{pm}$ & 1728 & 22.6 & 22 & 22.3 & 56.3 \\
\hline $\begin{array}{l}\text { 25- } \\
\text { Apr }\end{array}$ & 73 & $2 \mathrm{pm}$ & 1753 & 22.5 & 22 & 22.25 & 56.2 \\
\hline $\begin{array}{l}\text { 26- } \\
\text { Apr }\end{array}$ & 74 & $1 \mathrm{pm}$ & 1776 & 22.5 & 22 & 22.25 & 56.2 \\
\hline $\begin{array}{l}\text { 27- } \\
\text { Apr }\end{array}$ & 75 & $1 \mathrm{pm}$ & 1800 & 22.5 & 21.9 & 22.2 & 56.1 \\
\hline $\begin{array}{l}\text { 27- } \\
\text { Apr }\end{array}$ & 75 & $1 \mathrm{pm}$ & 1800 & 22.5 & 21.9 & 22.2 & 56.1 \\
\hline $\begin{array}{l}28- \\
\text { Apr }\end{array}$ & 76 & $1 \mathrm{pm}$ & 1824 & 22.3 & 22 & 22.15 & 56 \\
\hline $\begin{array}{l}\text { 29- } \\
\text { Apr }\end{array}$ & 77 & $1 \mathrm{pm}$ & 1848 & 22.3 & 21.6 & 21.95 & 55.9 \\
\hline $\begin{array}{l}\text { 30- } \\
\text { Apr }\end{array}$ & 78 & $1 \mathrm{pm}$ & 1872 & 22.4 & 21.7 & 22.05 & 55.7 \\
\hline $\begin{array}{c}1- \\
\text { May }\end{array}$ & 79 & $1 \mathrm{pm}$ & 1896 & 22.5 & 21.9 & 22.2 & 55.5 \\
\hline $\begin{array}{c}2- \\
\text { May }\end{array}$ & 80 & $1 p m$ & 1920 & 22.3 & 22 & 22.15 & 55.5 \\
\hline $\begin{array}{c}\text { 4- } \\
\text { May }\end{array}$ & 82 & $1 \mathrm{pm}$ & 1968 & 22.4 & 22.1 & 22.25 & 55.6 \\
\hline $\begin{array}{c}\text { 6- } \\
\text { May }\end{array}$ & 84 & $1 \mathrm{pm}$ & 2016 & 22.7 & 22.4 & 22.55 & 55.4 \\
\hline $\begin{array}{c}\text { 7- } \\
\text { May }\end{array}$ & 85 & $1 p m$ & 2040 & 22.9 & 22.4 & 22.65 & 55.2 \\
\hline $\begin{array}{c}\text { 8- } \\
\text { May }\end{array}$ & 86 & $1 \mathrm{pm}$ & 2064 & 22.6 & 22.1 & 22.35 & 55.5 \\
\hline
\end{tabular}

Table 14: Phase 3 - Corrected Tension

\begin{tabular}{|c|c|c|}
\hline Date & Tension (lbs) & Corrected Tension(lbs) \\
\hline $11-\mathrm{Feb}$ & 64.9 & 64.915 \\
\hline $12-\mathrm{Feb}$ & 64.1 & 64.11 \\
\hline $13-\mathrm{Feb}$ & 63.8 & 63.79 \\
\hline $14-\mathrm{Feb}$ & 63.5 & 63.525 \\
\hline $15-\mathrm{Feb}$ & 63.1 & 63.145 \\
\hline $16-\mathrm{Feb}$ & 62.5 & 62.63 \\
\hline $17-\mathrm{Feb}$ & 62.2 & 62.345 \\
\hline $18-\mathrm{Feb}$ & 61.9 & 62.04 \\
\hline $19-\mathrm{Feb}$ & 61.9 & 62.03 \\
\hline $20-\mathrm{Feb}$ & 61.4 & 61.565 \\
\hline $21-\mathrm{Feb}$ & 61.3 & 61.455 \\
\hline $22-\mathrm{Feb}$ & 61.2 & 61.36 \\
\hline $23-\mathrm{Feb}$ & 61 & 61.175 \\
\hline
\end{tabular}




\begin{tabular}{|c|c|c|}
\hline 24-Feb & 60.9 & 61.085 \\
\hline $25-\mathrm{Feb}$ & 61 & 61.15 \\
\hline 26-Feb & 61.2 & 61.375 \\
\hline 27-Feb & 60.9 & 61 \\
\hline 28-Feb & 61 & 61.065 \\
\hline 1-Mar & 60.7 & 60.76 \\
\hline 2-Mar & 60.4 & 60.505 \\
\hline 3-Mar & 60 & 60.13 \\
\hline 4-Mar & 60.1 & 60.225 \\
\hline 5-Mar & 60.3 & 60.355 \\
\hline 6-Mar & 60 & 60.07 \\
\hline 7-Mar & 60.2 & 60.2 \\
\hline 8-Mar & 59.8 & 59.845 \\
\hline 9-Mar & 59.5 & 59.565 \\
\hline 10-Mar & 59.1 & 59.22 \\
\hline 11-Mar & 58.9 & 59.025 \\
\hline 12-Mar & 58.7 & 58.855 \\
\hline 13-Mar & 58.3 & 58.48 \\
\hline 14-Mar & 58.2 & 58.41 \\
\hline 15-Mar & 58 & 58.23 \\
\hline 16-Mar & 58.1 & 58.33 \\
\hline 17-Mar & 58.1 & 58.305 \\
\hline 18-Mar & 58.5 & 58.625 \\
\hline 19-Mar & 58.6 & 58.7 \\
\hline 20-Mar & 58.5 & 58.6 \\
\hline 21-Mar & 58.4 & 58.49 \\
\hline 22-Mar & 58.2 & 58.305 \\
\hline 23-Mar & 57.6 & 57.785 \\
\hline 24-Mar & 57.3 & 57.505 \\
\hline 25-Mar & 57.2 & 57.435 \\
\hline 26-Mar & 57 & 57.245 \\
\hline 27-Mar & 57.5 & 57.635 \\
\hline 28-Mar & 57.5 & 57.625 \\
\hline 29-Mar & 57.4 & 57.51 \\
\hline 30-Mar & 57.5 & 57.605 \\
\hline 31-Mar & 57.3 & 57.44 \\
\hline 1-Apr & 56.8 & 57.03 \\
\hline 2-Apr & 56.5 & 56.725 \\
\hline 3-Apr & 56.1 & 56.36 \\
\hline 4-Apr & 56.5 & 56.73 \\
\hline 5-Apr & 56 & 56.27 \\
\hline
\end{tabular}




\begin{tabular}{|c|c|c|}
\hline 6-Apr & 56.8 & 56.93 \\
\hline 7-Apr & 56.8 & 56.925 \\
\hline 8-Apr & 56.7 & 56.85 \\
\hline 9-Apr & 57 & 57.115 \\
\hline 10-Apr & 56.9 & 57.01 \\
\hline 11-Apr & 56.9 & 57.015 \\
\hline 12-Apr & 56.7 & 56.805 \\
\hline 13-Apr & 56.6 & 56.73 \\
\hline 14-Apr & 56.6 & 56.7 \\
\hline 15-Apr & 56.4 & 56.515 \\
\hline 16-Apr & 56.5 & 56.605 \\
\hline 17-Apr & 56.3 & 56.41 \\
\hline 18-Apr & 56.1 & 56.215 \\
\hline 19-Apr & 56.2 & 56.33 \\
\hline 20-Apr & 56.4 & 56.505 \\
\hline 21-Apr & 56.4 & 56.515 \\
\hline 22-Apr & 56.4 & 56.525 \\
\hline 23-Apr & 56.4 & 56.515 \\
\hline 24-Apr & 56.3 & 56.43 \\
\hline 25-Apr & 56.2 & 56.325 \\
\hline 26-Apr & 56.2 & 56.325 \\
\hline 27-Apr & 56.1 & 56.22 \\
\hline 28-Apr & 56 & 56.115 \\
\hline 29-Apr & 55.9 & 55.995 \\
\hline 30-Apr & 55.7 & 55.805 \\
\hline 1-May & 55.5 & 55.62 \\
\hline 2-May & 55.5 & 55.615 \\
\hline 4-May & 55.6 & 55.725 \\
\hline 6-May & 55.4 & 55.555 \\
\hline 7-May & 55.2 & 55.365 \\
\hline 8-May & 55.5 & 55.635 \\
\hline 9-May & 55.3 & 55.425 \\
\hline
\end{tabular}

\subsection{Phase 4 Data}

Table 15: Phase 4 - Basic Cable

\begin{tabular}{|c|c|c|c|c|c|c|c|}
\hline Date & Day & Time & $\begin{array}{c}\text { Total Time } \\
(\mathrm{hrs})\end{array}$ & $\begin{array}{c}\text { Temperature } \\
1\left({ }^{\circ} \mathrm{C}\right)\end{array}$ & $\begin{array}{c}\text { Temperature 2 } \\
\left({ }^{\circ} \mathrm{C}\right)\end{array}$ & $\begin{array}{c}\text { Average } \\
\text { Temperature }\left({ }^{\circ} \mathrm{C}\right)\end{array}$ & $\begin{array}{c}\text { Tension } \\
(\mathrm{lbs})\end{array}$ \\
\hline $\begin{array}{c}10- \\
\text { May }\end{array}$ & 0 & $\mathrm{X}$ & 0 & 22.5 & 22.1 & 22.3 & 65.2 \\
\hline $\begin{array}{c}11- \\
\text { May }\end{array}$ & 1 & $\mathrm{X}$ & 24 & 22.2 & 22 & 22.1 & 65.5 \\
\hline
\end{tabular}




\begin{tabular}{|c|c|c|c|c|c|c|c|}
\hline $\begin{array}{l}\text { 12- } \\
\text { May }\end{array}$ & 2 & $x$ & 48 & $x$ & $x$ & $x$ & $x$ \\
\hline $\begin{array}{l}\text { 13- } \\
\text { May }\end{array}$ & 3 & $x$ & 72 & 22.7 & 22.1 & 22.4 & 65.7 \\
\hline $\begin{array}{l}\text { 14- } \\
\text { May }\end{array}$ & 4 & $x$ & 96 & 22.8 & 22.2 & 22.5 & 65.7 \\
\hline $\begin{array}{l}15- \\
\text { May }\end{array}$ & 5 & $x$ & 120 & 23 & 22.6 & 22.8 & 65.5 \\
\hline $\begin{array}{l}\text { 16- } \\
\text { May }\end{array}$ & 6 & X & 144 & 23 & 22.5 & 22.75 & 65.2 \\
\hline $\begin{array}{l}\text { 17- } \\
\text { May }\end{array}$ & 7 & $x$ & 168 & 22.6 & 22.3 & 22.45 & 65.5 \\
\hline $\begin{array}{l}\text { 18- } \\
\text { May }\end{array}$ & 8 & $X$ & 192 & $x$ & $x$ & $x$ & $x$ \\
\hline $\begin{array}{l}\text { 19- } \\
\text { May }\end{array}$ & 9 & X & 216 & $x$ & X & $x$ & $x$ \\
\hline $\begin{array}{l}20- \\
\text { May }\end{array}$ & 10 & $x$ & 240 & 23 & 22.6 & 22.8 & 65 \\
\hline $\begin{array}{l}\text { 21- } \\
\text { May }\end{array}$ & 11 & $x$ & 264 & 23.1 & 22.7 & 22.9 & 65.1 \\
\hline $\begin{array}{l}\text { 22- } \\
\text { May }\end{array}$ & 12 & $x$ & 288 & 23.7 & 22.2 & 22.95 & 65.2 \\
\hline $\begin{array}{l}\text { 23- } \\
\text { May }\end{array}$ & 13 & $x$ & 312 & 23.3 & 22.8 & 23.05 & 64.8 \\
\hline $\begin{array}{l}\text { 24- } \\
\text { May }\end{array}$ & 14 & $x$ & 336 & 23.5 & 23 & 23.25 & 65.1 \\
\hline
\end{tabular}

Table 16: Phase 4 - Corrected Tension

\begin{tabular}{|c|c|c|}
\hline Date & Tension (lbs) & Corrected Tension(lbs) \\
\hline 10-May & 65.2 & 65.33 \\
\hline 11-May & 65.5 & 65.61 \\
\hline 12-May & $\mathrm{X}$ & $\mathrm{X}$ \\
\hline 13-May & 65.7 & 65.85 \\
\hline 14-May & 65.7 & 65.88 \\
\hline 15-May & 65.5 & 65.675 \\
\hline 16-May & 65.2 & 65.345 \\
\hline 17-May & 65.5 & 65.68 \\
\hline 18-May & $\mathrm{X}$ & $\mathrm{X}$ \\
\hline 19-May & $\mathrm{X}$ & 65.18 \\
\hline 20-May & 65 & 65.29 \\
\hline 21-May & 65.1 & 65.395 \\
\hline 22-May & 65.2 & 65.005 \\
\hline 23-May & 64.8 & \\
\hline
\end{tabular}


65.1

65.325 